\author{
ADRIAN WESOEOWSKI \\ Uniwersytet Warszawski \\ Instytut Antropologii Społecznej Maxa Plancka \\ Halle an der Saale, Niemcy
}

\title{
NIEŚMIERTELNY I DOBROCZYNNY. HISTORYCZNE BADANIE GENEZY I CHARAKTERU SŁAWY STANISŁAWA STASZICA
}

\begin{abstract}
Abstrakt: Artykuł zadaje pytania o niezwykłą popularność Stanisława Staszica (1755-1826), której kulminacją był jego pogrzeb - spontaniczna manifestacja uczuć patriotycznych tysięcy mieszkańców Warszawy. Autor twierdzi, że postać Staszica była postrzegana przez pryzmat działalności filantropijnej, opisuje ewolucję jego wizerunku jako filantropa oraz prezentuje pogłębioną kontekstualizację źródeł tej popularności.
\end{abstract}

Słowa kluczowe: Stanisław Staszic, filantrop, sława, bohater, tożsamość zbiorowa.
Abstract: The article asks questions about the unusual popularity of Stanisław Staszic (1755-1826), that culminated during his funeral - a spontaneous manifestation of patriotic feelings of thousands Varsovians. The author maintains that the figure of Staszic was perceived by a prism of his philanthropic activity and describes the evolution of his image as philanthropist, offering at the same time a broadened contextualization of the reasons for such popularity.

Keywords: Stanisław Staszic, philanthropist, fame, hero, collective identity.

Pogrzeb zmarłego 20 stycznia 1826 r. Stanisława Staszica, który odbył się cztery dni później, był w oczach wielu wydarzeniem bezprecedensowym. Miała to być jedna z najwspanialszych uroczystości w stolicy, porównywalna do symbolicznej ceremonii pogrzebowej cara Aleksandra I, a może nawet ją przerastająca ${ }^{1}$. Pamiętnikarze podkreślali jej znaczenie oraz

${ }^{1}$ Funeralia porównywali Joachim Lelewel, Polska odradzająca się, czyli dzieje polskie od roku 1795 potocznie opowiedziane, Bruksela 1836, s. 56 i Tymoteusz Lipiński, Zapiski z lat 1825-1831, do dr. przygot. i przypisami objaśnił K. Bartoszewicz, Kraków 1883, s. 17. Por. K. Koźmian, Pamiętniki obejmujące wspomnienia od roku 1780 do roku 1815, t. 2, Poznań 1858, s. 251-252; F. Skarbek, Pamiętniki, Poznań 1878, s. 101. 
emocjonalny wpływ, jaki miała ona wywrzeć na mieszkańców Warszawy. Zachowana korespondencja potwierdza to wrażenie. Warszawska prasa roku 1826 poświęciła pogrzebowi niespotykanie wiele miejsca. Dziwi ta uniwersalna pochwała Staszica, gdyż za życia budził wiele kontrowersji. Tymczasem do grobu odprowadzała go krajowa elita: namiestnik Józef Zajączek, prymas Wojciech Skarszewski, senatorowie, ministrowie, Rada Stanu, wysocy rangą duchowni, zgromadzenie członków Królewskiego Warszawskiego Towarzystwa Przyjaciół Nauk, artyści Teatru Narodowego. Przejęci mieszkańcy stolicy zamykali sklepy i spontanicznie dołączali do pochodu, który liczył, w świetle różnych relacji, od „kilku” do trzydziestu tysięcy osób (niemalże $1 / 4$ ludności Warszawy) ${ }^{2}$. Zagadkowo silnie pozytywny odbiór zmarłego wyrażał się w entuzjazmie tłumów. Drogę na podwarszawskie Bielany przebyto, nie zważając na mróz i śnieg. Mówców noszono na ramionach i wymieniano $\mathrm{z}$ nimi uściski. Zaszczyt niesienia trumny stał się przedmiotem kłótni pomiędzy młodymi akademikami a kupcami warszawskimi. Napięcie eskalowało w momencie opuszczenia ciała do grobu, kiedy żałobnicy „odarli trumnę z miłości i entuzjazmu”, tzn. rozdarli między siebie całun, fragmenty zachowując na pamiątkę ${ }^{3}$. Ten „szał uwielbienia” i powszechna żałoba miały być „wymuszone na każdym i na całej opinii publicznej, przez wpływ, jaki wywierać musiał na umysłach rzadki przykład człowieka, który nic nie robił dla siebie, a wszystko poświęcał dla dobra ludzkości i ojczyzny swojej"”.

Frekwencja i entuzjazm uczestników pogrzebu zaskakiwały współczesnych. „Mówię, że były wymuszone - pisał Fryderyk Skarbek - bo Staszic nie należał do rzędu ludzi, którzy słodyczą charakteru i uprzejmości przyciągają do siebie i jednają sobie przychylność". Nie tylko osobowość zmarłego wydawała się problematyczna. Dostrzegano również, że „nie używał politycznej popularności, że był wysoko ceniony przez władze, a w szczególności namiestnika, że - słowem - nie był tym koryfeem opinii publicznej, którego okrzykami witają i na rękach noszą"5. A jednak wydarzenie przyciągało każdego w niezrozumiały sposób: „mając

${ }^{2}$ Najniższe szacunki znaleźć można w raportach carskiej policji (zob. B. Szacka, Stanisław Staszic, Warszawa 1966, s. 233), a najwyższy pada w opowiadaniu Stanislaus Staszyc oder der erlauchte Geizige, „Thorner Wochenblatt” 1842, 41, s. 508-511. Często pisze się również o liczbie 14 oraz 20 tys. osób.

${ }^{3}$ Fryderyk Chopin (Warszawa, Królestwo Kongresowe) do Jana Białobłockiego w Biskupcu, 12 lutego 1826 r., transkrypcja i dokument zdigitalizowany, w: Korespondencja Fryderyka Chopina, oprac. Z. Helman, Z. Skowron, H. Wróblewska-Straus, t. 1: 1816-1831, Warszawa 2009, s. 154.

${ }^{4}$ F. Skarbek, op. cit., s. 99.

${ }^{5}$ Ibidem, s. 99-100. 
zamiar odprowadzić tylko zwłoki do rogatek, nie mogłem się oprzeć sam sobie; widząc z jakim uniesieniem niezliczony natłok postępował drogą ku Bielanom, zaszedłem tamże ochoczo". W tych okolicznościach, wszystkich superlatyw, które znajdują się we wspomnianych źródłach, nie można postrzegać tylko jako wyraźnego przykładu retoryki typowej dla ówczesnej literatury funeralnej. Zadać należy pytanie o przyczyny szczególnej popularności Staszica. Do dziś nie dysponujemy przekonującym wyjaśnieniem tego zjawiska.

W kontekście badań nad wiekiem XIX tematy popularności, publicznego odbioru czy sławy korelują z przeprowadzanymi wcześniej analizami kultu jednostek. Historiografia polska zna prace poświęcone bohaterskim przedstawieniom takich postaci, jak Napoleon Bonaparte ${ }^{7}$, Tadeusz Kościuszko ${ }^{8}$, książę Józef Poniatowski ${ }^{9}$ czy Józef Piłsudski ${ }^{10}$. Zainteresowanie tematem nie przyniosło jednak podstaw do szerszej teoretyzacji problemu. Sam Staszic jest obiektem badań stale interesującym historyków od niemalże dwustu lat ${ }^{11}$. Jakkolwiek nie podejmowano się rozstrzygnięcia problemu jego sławy, wydaje się, że wciąż oddziałuje ona na ludzi nim zafascynowanych ${ }^{12}$.

Inną perspektywę oferują coraz popularniejsze na Zachodzie studia nad sławą (celebrity studies). Choć pozbawione jednolitej metody,

${ }^{6}$ T. Lipiński, op. cit., s. 20.

${ }^{7}$ Np. A. Zahorski, Z dziejów legendy napoleońskiej w Polsce, Warszawa 1971; S. Treugutt, Napoleon Bonaparte jako bohater polskiego romantyzmu, „Teksty” 17, 1974, 5, s. 37-44; J. Laske, Z problematyki legendy napoleońskiej, w: Młoda Polska. Legendy i światopoglady, red. T. Bujnicki, J. Illg, Katowice 1983, s. 7-53; O rok ów... Epoka napoleońska w polskiej historiografii, literaturze, sztuce i tradycji, red. M.M. Drozdowski, H. Szwankowska, Warszawa 2003.

${ }^{8} \mathrm{~Np}$. K. Śreniowska, Kościuszko bohater narodowy. Opinie wspótczesnych i potomnych. 1794-1946, Warszawa 1973; K. Maksimowicz, Poetycka legenda Tadeusza Kościuszki (lata 1792-1794), „Wiek Oświecenia” 11, 1995 (W dwusetną rocznicę Powstania Kościuszkowskiego), s. 65-81.

${ }^{9}$ Np. H. Widacka, Les adieux de Poniatowski czyli legenda księcia Józefa Poniatowskiego w grafice XIX wieku, „Kronika Zamkowa” 1995, 1, s. 98-114; A. Pochodaj, Śmierć „polskiego Bayarda” - z legendy księcia Józefa Poniatowskiego, „Dzieła i Interpretacje” 4, 1996, s. $192-217$.

10 Np. A. Kowalczykowa, Piłsudski i tradycja, Chotomów 1991; M.B.B. Biskupski, Independence Day. Myth, Symbol and the Creation of Modern Poland, Oxford 2012.

11 Odsyłam do najpełniejszej bibliografii dotyczącej postaci: E. Aleksandrowska, Staszic Stanisław (1755-1826), w: Bibliografia Literatury Polskiej „Nowy Korbut”, t. 6: Oświecenie - hasła osobowe P-Ż, addenda A-O, oprac. E. Aleksandrowska z zespołem, red. tomu do r. 1958 T. Mikulski, Warszawa 1970, s. 219-235.

12 Patrz prace dotyczące tzw. postawy staszicowskiej, np. J. Olejniczak, Staszicowskie wzorce w społeczeństwie polskim w XIX i XX wieku. Zarys problematyki, „Rozprawy z Dziejów Oświaty" 45, 2006, s. 23-33. Warto wspomnieć również hegemonię Staszica jako wzorca w lokalnej sferze publicznej, np. w Pile. 
dostarczają one narzędzi i ustaleń, które powoli są adaptowane dla potrzeb badań historycznych ${ }^{13}$. Cenny jest również sam punkt widzenia, według którego sławy nie traktuje się jako ubocznego efektu sytuacji historycznej lub emanacji wrodzonej charyzmy danej postaci, ale jako pełnoprawny przedmiot badań naukowych ${ }^{14}$. Na potrzeby tej pracy sława oznaczać będzie status wybitności przypisywany jednostce w obrębie sfery publicznej, który to proces uwzględnia interakcję trzech stron: szerokiej grupy odbiorców, pośredników w przekazie wizerunku oraz postaci otoczonej sławą. Interrelacja pomiędzy tymi aktorami, która określa charakter sławy, determinowana jest przez przekształcenia historyczne. Do tak postawionej definicji można czynić zastrzeżenia ${ }^{15}$, jednak ułatwia ona postawienie pytań badawczych związanych z pośmiertną popularnością Staszica. Specyficzna struktura niniejszego tekstu związana jest z przyjętą przeze mnie perspektywą. Pierwsza część poświęcona jest określeniu charakteru sławy Staszica. Omawiam w niej możliwe wyjaśnienia frekwencji i entuzjazmu na pochodzie pogrzebowym oraz przedstawiam własną propozycję: to wizerunek filantropa był odpowiedzialny za tak silnie pozytywną recepcję opisywanej postaci. Druga część tekstu przynosi pogłębioną kontekstualizację procesu budowania sławy Staszica - wyjaśniam w nim, jakie znaczenie dla ziem polskich tego okresu miała nowa formuła filantropii, dlaczego zaistniała wtedy potrzeba znalezienia nowych bohaterów oraz jak przemiany charakteru sławy wpłynęły na cały proces.

W rezultacie tekst przynosi kilka znaczących innowacji. Wydarzenia związane z tworzeniem filantropijnego wizerunku Staszica miały duży wpływ na kształt kultu filantropa jako archetypicznego dobroczyńcy. Kult ten objawiał się publiczną fascynacją postaciami społeczników, szczególnym miejscem, jakie wydarzenia związane z nimi zajmowały w prasie, powstawaniem panegirycznych dzieł literackich im poświęconych, włączaniem ich do ludowych legend i tradycji, a w dłuższej perspektywie upamiętnianiem ich jako herosów. W Polsce wśród uwielbianych filantropów znajdowali się Ludwik Gąsiorowski, Adam Bogumił Helbich, Karol Marcinkowski, Joanna Neybaur, Klaudyna Potocka, Edward Raczyński, Matias Rosen, Jadwiga Sapieżyna, Emilia Sczaniecka, Jakub Szymkiewicz, Józef Torosiewicz czy Maria Wirtemberska. Powstały w ten sposób wzorzec, w pełni rozwinięty w drugiej połowie stulecia, wkroczył na stałe do

${ }^{13}$ W poniższym tekście odwoływać się będę głównie do badań Chrisa Rojeka, Graeme'a Turnera, P. Davida Marshalla i Antoine'a Liltiego.

${ }^{14}$ C. Rojek, Celebrity, London-New York 2004, s. 29-45.

${ }^{15}$ Ibidem, s. 10-13. 
wyobraźni literackiej i stał się jednym z najważniejszych modeli postaci w literaturze pozytywistycznej ${ }^{16}$. W tym sensie poniższy artykuł pomaga odpowiedzieć na pytania związane z początkiem krystalizacji kultu filantropa na ziemiach polskich.

Studium przypadku Staszica ma też znacznie szersze znaczenie dla metody badań sławy na gruncie historycznym. Wspomniane wcześniej prace z tematyki „kultu”, ,legendy” lub „mitu” sławnych postaci w przeważającej mierze skupiały się na opracowaniu faktografii, czyli przejawów takiego wywyższenia, rzadko kiedy poświęcając miejsce interpretacjom zebranego materiału. Fakt ten potwierdza przewaga ujęć literaturoznawczych oraz z zakresu historii sztuki. Niniejszy artykuł przynosi propozycję wyjścia poza pojedyncze fakty do poziomu analizy społecznej, co daje podstawę do szerszej dyskusji nad pokrewnymi zagadnieniami oraz metodologią podobnych badań. Tekst stanowi również odpowiedź na obecne od lat wśród badaczy celebrity wezwania do historyzowania kwestii sławy ${ }^{17}$.

Materiał źródłowy do podobnych badań jest niezwykle rozproszony. W pracy wykorzystano zróżnicowane typy źródeł (pamiętniki, mowy pogrzebowe, literaturę, wiersze, prasę i inne), odnoszące się do postaci Staszica, a także prace biograficzne oraz, sporadycznie, inne typy źródeł. Artykuł oparty jest na opracowaniach historycznych we fragmentach, które zakładają syntetyzowanie zastanej wiedzy naukowej. Niewielka część analizy odnosi się do prac samego Staszica. Problem autokreacji, jaki można badać na ich podstawie, stanowi osobne zagadnienie wykraczające poza ramy niniejszej analizy. Nie oznacza to jednak zmarginalizowania wizerunkowych działań postaci korespondujących z autokreacją literacką.

Przedstawione w drugiej części zarysowanie kontekstu wysławienia Staszica jako filantropa z konieczności jest skrótowe. Odwołuję się w nim do kwestii najistotniejszych oraz zagadnień mających bezpośredni wpływ na sławę. Rezultatem jest zawężony opis omawianych tam zjawisk, włączając w to problem recepcji idei filantropicznych na ziemiach polskich, tożsamości zbiorowej społeczeństwa polskiego oraz transformacji sposobu funkcjonowania osób sławnych w Europie. Całościowa analiza wymagałaby znacznie szerszego omówienia, rozciągnięcia ram

16 J. Tomkowski, Mój pozytywizm, Warszawa 1993, s. 78-96; H. Markiewicz, Pozytywizm, Warszawa 1999, s. 119-120; G. McCully, Philanthropy Reconsidered. Private Initiatives, Public Good, Quality of Life (A Catalogue for Philanthropy Publication), Bloomington 2008, rozdz. 1: „Promethean Fire. The Archetype”, s. 1-21.

17 J. Bennett, Historicising Celebrity Studies, „Celebrity Studies” 1, 2010, 3, s. 358-359; S. Morgan, Historicising Celebrity, „Celebrity Studies” 1, 2010, 3, s. 366-368; por. A. Wesołowski, „Celebrity studies” jako narzędzie dla historyka, „Historyka. Studia metodologiczne" 47, 2017, s. 325-332. 
czasowych pracy tak, aby ukazać, w jaki sposób grały one rolę w dziewiętnastowiecznej rzeczywistości społecznej, oraz sięgnięcia po inne typy źródeł. Ponieważ w poniższej pracy jedynie sygnalizuję te kwestie, aby lepiej wyjaśnić przedmiot moich badań, w przypisach odsyłam do dojrzalszych opracowań tematycznych.

\section{Część 1 . Charakter sławy Staszica}

Przypadek pogrzebu Staszica jest szczególny ze względu na kilka okoliczności. Trudno jest go wyjaśnić politycznym autorytetem postaci w obliczu mniejszej popularności pochówków innych dygnitarzy, które odbyły się $\mathrm{w}$ tym samym okresie, np. senatora-kasztelana i ministra sprawiedliwości Franciszka Węgleńskiego w roku 1820, lub namiestnika Józefa Zajączka w lipcu 1826. Analogicznie odpierać można argument, według którego ceremonia otoczona była szczególną uwagą opinii publicznej ze względu na literacką lub naukową renomę Staszica. Wystarczy ją zestawić z relatywnie bliskimi czasowo pogrzebami Franciszka Zabłockiego czy Hugona Kołłątaja, czynnych literacko i politycznie niemal do śmierci, które, aczkolwiek widziane były przez współczesnych jako uroczyste, gromadziły jedynie wąskie kręgi intelektualne i artystyczne.

Z kolei próba przedstawienia pogrzebu Staszica jako „manifestacji uczuć patriotycznych" jest o tyle sensowna, o ile powierzchowna i problematyczna. Podczas ceremonii podnoszono tematy narodowe, a nawet wyzwoleńcze - np. mowa pogrzebowa referendarza Wojciecha Grzymały, niezrozumiała dla wielu zebranych, została entuzjastycznie przyjęta przez młodzież akademicką jako manifest wyzwoleńczy ${ }^{18}$. Staszic nie był jednakże typowym bohaterem narodowym. Ta sama młodzież dawała wyraz wściekłości po podpisaniu przez niego dekretu o cenzurze w roku 1819, czego eskalacją była propozycja postawienia ministra przed sądem, wysunięta przez Bonawenturę i Wincentego Niemojowskich, przywódców parlamentarnej opozycji ${ }^{19}$. Staszic spotkał się też z krytyką ze strony opi-

18 Współcześni wiązali ten dualizm z walką romantyzmu i klasycyzmu. Opisując mowę Grzymały, Kajetan Koźmian zacytował Ludwika Osińskiego, który pisał: „słysząc te ciemne i enigmatyczne wysłowienia, a zarazem widząc uniesienia młodzieży, wpadłem na domysł, że jak uwielbienie jej dla dzisiejszej poezyi, tak i dla tej mowy, pochodzi ze znaczenia tajemnicznego, które dla nas jest niezrozumiałem" (za: A. Kraushar, Towarzystwo Królewskie Przyjaciót Nauk, 1800-1832. Monografia historyczna osnuta na źródłach, ks. 3, Kraków 1905, s. 223-224).

19 Mowa o skardze złożonej 12 października 1820 r. przeciwko Staszicowi i Stanisławowi Kostce Potockiemu, w imieniu którego Staszic jako zastępca podpisał 
niotwórczych środowisk kościelnych, które reagowały negatywnie na jego kontrowersyjne wypowiedzi na temat kleru oraz ambiwalentną postawę wobec pełnienia funkcji duchownego ${ }^{20}$. Problematyczny jest również charakter heroizmu Staszica. Postaci, które do tej pory nazywano bohaterami narodowymi, związane były ze wzorcem wojownika i walką zbrojną, jak np. Tadeusz Kościuszko czy książę Józef Poniatowski. Pokojowa uległość Staszica nie wpasowywała się w ten model. Mimo że istniało wiele podobieństw w sposobie ich wywyższenia - wzbudzali oni ogromną fascynację tłumów, ich śmierć inspirowała poetów i pisarzy, a później biografów do tworzenia wielu utworów, w dużej mierze pochwalnych młodzieży akademickiej, która stanowiła najbardziej entuzjastyczną grupę na pogrzebie Staszica i z której pochodziło wielu autorów późniejszych wierszy na jego temat, dużo bliżej było do romantycznego ideału żołnierza niż do postaci skromnego ministra. Staszic mógł być bliższy tym grupom, które rozumiały patriotyzm jako działanie nienawiązujące do walki zbrojnej, np. zwolennikom pracy organicznej avant la lettre, również poprzez panslawistyczne idee, do których często się odwoływał ${ }^{21}$.

Nie można zignorować faktu, że w latach dwudziestych XIX w. odbyło się więcej takich uroczystych pogrzebów. Pochówki ministra Stanisława Kostki Potockiego oraz gen. Stanisława Mokronowskiego w 1821 r. również zgromadziły liczne honorowe orszaki pogrzebowe ${ }^{22}$. Miały też wtedy miejsce pierwsze manifestacyjne pogrzeby aktorów ${ }^{23}$. Jednakże, o ile należy sądzić, że pożegnanie Staszica wpisywało się w pewien trend związany z heroizacją zmarłych, nie sposób odjąć mu wyjątkowości. Porównywane do starannie dopracowanego pogrzebu Aleksandra I (w kwietniu 1826 r.) oraz tłumnej procesji z ciałem prymasa Skarszewskiego (1827), wyróżniało się spontanicznością uczestników i silną oddolną reakcją ${ }^{24}$. Pociągnęło też za sobą falę twórczości literackiej, którą trudno wyjaśnić przywiązaniem do instytucji państwa lub Kościoła. Prefiguracyjne pochówki z 1821 r. nie mogły się z nim równać pod względem relacji

ustawę. Patrz: Dziennik posiedzeń Izby Poselskiey w czasie seymu Królestwa Polskiego w roku 1820 odbytego, Warszawa [1820], s. 64.

${ }^{20}$ K. Koźmian, Pamiętniki, s. 255.

${ }^{21}$ T. Matlęgiewicz, Program słowiański Staszica po postanowieniach kongresu wiedeńskiego, „Przegląd Nauk Historycznych” 10, 2011, 1, s. 187-204.

${ }^{22}$ Jeśli ufać relacjom prasowym i pamiętnikarskim, reakcja społeczna na pogrzebie Staszica w znacznym stopniu przerastała te z roku 1821. To tylko przy jego okazji podaje się też szacowaną liczbę uczestników, zob. „Kurier Warszawski” 1821, nry 224, 231, 252, 253.

${ }^{23}$ Encyklopedia teatru polskiego, oprac. B. Frankowska, Warszawa 2003, s. 579.

${ }^{24}$ Zwracał na to uwagę Tymoteusz Lipiński, op. cit., s. 22-23. 
prasowych i pamiętnikarskich. W końcu na żadnym z nich nie ewokowano nowego wzorca społecznego, jakim w tym okresie był świecki filantrop, jako dominującej interpretacji postaci zmarłego.

\section{Staszic jako filantrop}

W najnowszej literaturze historycznej zwykle marginalizuje się tę sferę jego działalności i w najlepszym wypadku przedstawia dobroczynność jako jedno z wielu zajęć, których się podejmował. Tymczasem Staszic w wieku XIX znany był przede wszystkim właśnie jako filantrop. Świadczą o tym m.in. liczne prace, które starały się podkreślić filantropijny wizerunek postaci, również poprzez zawarcie tego terminu w tytule ${ }^{25}$. Wiktor Hahn pisał jeszcze w 1926 r., że ,jako filantrop nie ma Staszic równych sobie w Polsce" 26 . Właśnie w taki sposób minister odbierany był też za granicą. We francuskiej encyklopedii biograficznej Louisa-Gabriela Michauda (1773-1858) pod jego nazwiskiem znaleźć można objaśnienie rozpoczynające się od słów: „écrivain et philanthrope polonais”27.

Za odejście od myślenia o Staszicu jako filantropie odpowiadać może okres pomiędzy latami 1952-1984, kiedy to najbardziej powszechna forma działalności charytatywnej została zdelegalizowana wraz z Dekretem o zniesieniu fundacji z dnia 24 kwietnia $1952 \mathrm{r}^{28}$ (w $1984 \mathrm{r}$. przywrócono możliwość powoływania fundacji ${ }^{29}$ ). Indywidualne przedsięwzięcia dobroczynne stały się również częścią negatywnego stereotypu związanego z prywatną przedsiębiorczością czy też „prywatną inicjatywą", którą napiętnował aparat propagandowy PRL ${ }^{30}$. Wizerunek

25 Przykłady takich prac to: Uwagi nad politycznym, naukowym i filantropijnym działaniem S. Staszica, Poznań 1873; J. Goldszmit, Dobroczyńca, jakich mało. Ksiądz Stanisław Staszic jako filantrop i mąż stanu. Szkic biograficzny, Warszawa 1882; F.S. Krysiak, Staszic jako polityk, uczony i filantrop, „Tygodnik Przemysłowy” 4, 1888, 2, s. 12-24; S. Cieszkowski, Stanisław Staszic. Filantrop, mąz stanu i uczony, ur. $1755 \mathrm{zm}$. 1826. Zarys biograficzny w setna rocznice zgonu, Warszawa 1925; T. Turkowski, O życiu i pracach Stanisława Staszica, dobroczyńcy narodu polskiego, Wilno 1926; F. Koneczny, Kultura czynu u Staszica, w: Stanisław Staszic 1755-1826. Księga zbiorowa, red. Z. Kukulski, Lublin 1926-1928, s. 71-80.

${ }^{26}$ W. Hahn, Stanisław Staszic. Życie i dzieła (z portretem Staszica), Lublin 1926, s. 96.

27 Staszic (Stanislas), w: Biographie universelle ancienne et moderne: histoire par ordre alphabétique de la vie publique et privée de tous les hommes, red. L.G. Michaud, t. 40, Paris 1843 , wyd. 2, s. 173-174. Por. $\mathrm{z}$ biogramem Staszica w anglojęzycznym czasopiśmie „Polonia” 2, 1832, 5, s. 343-347.

28 „Dziennik Ustaw” 1952, nr 25, poz. 172.

29 „Dziennik Ustaw” 1984, nr 21, poz. 97.

30 Zob. K. Gołata, Transformacja gospodarcza - nowe pojęcie przedsiębiorcy, „Zeszyty Naukowe Wyższej Szkoły Bankowej w Poznaniu" 24, 2009, s. 174-181. 
indywidualisty-filantropa został w tym okresie zmarginalizowany, a skupiono się na opisywaniu dokonań Staszica mieszczących się w zinstytucjonalizowanej formule działalności publicznej.

Wśród prac, które zwykle wymienia się jako najwybitniejsze osiągnięcia dobroczynne Staszica, znajdują się: wsparcie Szpitala Dzieciątka Jezus w Warszawie sumą 200 tys. zł, fundowanie stypendiów studenckich i mecenat nad nauką oraz sztuką (z czego najsłynniejszym uczynkiem było opłacenie budowy pomnika Mikołaja Kopernika w Warszawie), przeznaczenie kolejnych 200 tys. zł na utworzenie domu pracy na wzór instytucji holenderskich, przekazanie Towarzystwu Przyjaciół Nauk nowych siedzib, włącznie ze znacznym wkładem finansowym we wzniesienie pałacu w miejscu dawnego kościoła Dominikanów, zwanego później Pałacem Staszica, oraz fundacja Towarzystwa Hrubieszowskiego, pierwowzoru polskiej spółdzielczości, w ramach którego rolnicy zobowiązywali się do wzajemnej pomocy oraz otrzymywali na własność ziemię darowaną przez fundatora.

To ostatnie przedsięwzięcie przyniosło Staszicowi faktyczną sławę filantropa i zostało publicznie docenione po raz pierwszy na posiedzeniu Towarzystwa Przyjaciół Nauk w 1824 r., kiedy odbyła się potajemnie zaplanowana pochwała prezesa jako dobroczyńcy Hrubieszowa. Z mową wystąpił Fryderyk Skarbek i jako „tłumacz uczuć swoich kolegów” wyraził podziw i zachwyt, jaki budził w członkach TPN Staszic. Przemówienie zwieńczyły oklaski i liczne gratulacje z okazji dokonania tak wspaniałego czynu $^{31}$. O sympatii i aprobacie, którą Staszic cieszył się wśród członków TPN, świadczy również jego wielokrotna reelekcja na stanowisko prezesa Towarzystwa. Podobnie silny entuzjazm dla działalności Staszica wyrażał jego bliski współpracownik, Kajetan Koźmian - po śmierci filantropa przybrał go sobie na patrona pióra podczas pisania Ziemiaństwa polskiego. W pierwszej pieśni swego dzieła wzywał go do tego zadania, powołując się na inspirację, którą czerpać można $\mathrm{z}$ widoku uszczęśliwionych mieszkańców Hrubieszowa ${ }^{32}$. W tych momentach, kiedy mowa była o filantropijnych osiągnięciach Staszica, Skarbek, Koźmian i inni wpadali w uniesienie i wzniosły ton. „Ten mędrzec, ten filozof, filantrop" - wyliczał Koźmian, pisząc o zasługach przyjaciela ${ }^{33}$.

${ }^{31}$ Najobszerniej opisany w: F. Skarbek, op. cit., s. 92-99.

${ }^{32}$ Fragment Ziemiaństwa polskiego, o którym mowa: „Ludzkości! ty mnie natchnij, twoją śpiewam sprawę, / A ty do powziętego przewodnicz zawodu, / Mędrcze! i rolniczego dobroczyńco rodu! / Pójdźmy do Hrubieszowa kwitnącej ustroni, / Ty z ustawą swobody, a ja z fletem w dłoni" (K. Koźmian, Ziemiaństwo polskie. Poema w cztérech pieśniach, Wrocław 1839, s. 4).

${ }^{33}$ K. Koźmian, Pamiętniki, s. 237. 
Skarbek mówił o nim: „dobroczyńca całego świata” i „wzór rzadkiej cnoty" ${ }^{34}$. Środowiskowy prestiż, jakim cieszył się Staszic jako filantrop, wyrażał się również w idealizacji, która mogła być źródłem dla późniejszej recepcji postaci.

Aby jednak wizerunek Staszica filantropa zaczął być znany szerszym kręgom społecznym, potrzeba było wydarzenia, które rozpowszechniłoby i uczyniło jego postać bardziej przystępną dla mas, odprowadzających później ciało swojego bohatera do bielańskiego grobu. Takim wydarzeniem była jego śmierć i ogłoszenie dobroczynnego testamentu, który odbił się echem w całej Europie. Cały ogromny majątek ministra przeznaczony miał być na instytucje dobra publicznego. Niewiele zapisano na uposażenie służby oraz na sam pogrzeb; w zamyśle miał być on skromny, a pieniądze zwyczajowo przeznaczane na palenie świec przy trumnie Staszic polecił rozdać ubogim. Efekt był szybko widoczny. Mowy pogrzebowe wtórowały wcześniejszym zachwytom członków TPN. Podkreślano w równym stopniu patriotyczne i filantropijne motywacje zmarłego. W jednej z nich Skarbek wyraźnie oddzielał Staszica od wcześniej znanych filantropów: „liczyła już ludzkość wielu takich dobroczyńców, którzy przepędziwszy życie w swobodnym dostatków używaniu, wielkie majątki wsparciu cierpiących lub dobru pospolitemu poświęcili, lecz mało nader w dziejach świata znajdziesz przykładów takich, którzyby z uszczerbkiem własnych potrzeb i przyjemności pożycia na to tylko gromadzili majątek, aby go potem, jako źródło dobra pospolitego, na kraj własny wylać" 35 . Mowa ta była publikowana w licznych czasopismach i wkrótce wydana w postaci książki, czym Skarbek chełpił się w swoich pamiętnikach. Z kolei kazanie ks. Wojciecha Szweykowskiego zbudowane było wokół podobnego pytania, co niniejszy artykuł. Odrzucając różne przyczyny olbrzymiej frekwencji na pogrzebie Staszica, Szweykowski znajdował najbardziej przekonującą w tym, że „Staszic nie żył dla siebie; żył nie dla maksym zwyczajnych: dlatego Opatrzność Boska wspierała jego usiłowania. To go wyniosło z rzędu ludzi pospolitych, to mu zjednało szacunek powszechny"36, tzn. upatrywał przyczyn popularności zmarłego w jego altruistycznej postawie.

Na ten sam aspekt uwagę zwracała prasa informująca o śmierci ministra. To ona była $\mathrm{w}$ dużej mierze odpowiedzialna za rozprzestrzenianie

${ }^{34}$ F. Skarbek, op. cit., s. 97-99.

${ }^{35}$ F. Skarbek, W. Szweykowski, W. Grzymała, Zbiór mów na obchodzie pogrzebowym x. Stanisława Staszica, ministra stanu, dyrektora jeneralnego przemysłu i kunsztów, prezesa Towarzystwa Królewskiego Warszawskiego Przyjaciół Nauk, kawalera Orderu Orła Białego i S. Stanisława I kl. itd., Warszawa 1826, s. 4-5.

${ }^{36}$ Ibidem, s. 7. 
informacji o zmarłym, a później jego pogrzebie. Autor tekstu zamieszczonego w "Gazecie Warszawskiej”, relacjonując szczegółowo uroczystość, wielokrotnie podkreślił, że zasługami zmarłego były „czyny dobroczynności i miłości bliźniego", zaś opis jego kariery urzędniczej, naukowej i literackiej sprowadził do zaledwie kilku słów ${ }^{37}$. Nekrolog w „Dzienniku Wileńskim”, po wymienieniu sprawowanych przez Staszica urzędów i zdawkowym zdaniu: „Znany jest Staszic w literaturze jako autor i tłumacz dzieł wielu", ponad połowę miejsca poświęcił opisowi zapisów testamentowych i fundacji hrubieszowskiej ${ }^{38}$. Jednak nawet nowinki związane $\mathrm{z}$ testamentem przedstawiane były wybiórczo: „Gazeta Warszawska” zamieściła notę na ten temat, w większości złożoną jednak z cytatu ze wstępu do dokumentu, w którym Staszic przedstawił swoje motywacje. Zasadnicza część zapisu została krótko podsumowana: „Tu następują dobroczynne różne zapisy, o których już różne pisma doniosły" ${ }^{39}$. Świadczy to dobrze o tym, że sama postać wielkiego filantropa interesowała tłumy w wiele większym stopniu niż szczegóły dotyczące akcji charytatywnych, których podejmował się przecież na długo przed swoją śmiercią. W „Rozmaitościach. Piśmie dodatkowym do Gazety Lwowskiej" zaobserwowano, jak nagła była fascynacja Staszicem filantropem: „Przez całe życie za skąpego miany, wolał ten zarzut przenieść na siebie jak swoje dobrodziejstwa ogłaszać, dopiero po śmierci pokazało się, ile łez otarła jego ręka, ilu nieszczęśliwym dała pomoc"40.

Śmierć Staszica była również inspiracją wielu utworów poetyckich. Większość autorów należała do warszawskich środowisk studenckich i narodowych, można się więc spodziewać, że byli oni związani z grupami biorącymi udział w pochodzie pogrzebowym lub też że sami w nim uczestniczyli. Wiersze publikowano wkrótce po pogrzebie ostatni ukazał się po raz pierwszy w marcu roku 1826. Są one dla nas istotnym źródłem, ponieważ ich autorzy w szczególny sposób zaznaczali filantropijny aspekt postaci Staszica. Dostrzegał to już Wilhelm Bruchnalski w swoim artykule z roku 1926. Jako przyczynę takiego odczytania postaci wskazywał on efektowność samej dobroczynności, która miała wpadać „aż nadto w oczy powszechności” i mogła „być udziałem najszerszych warstw społeczeństwa" 41 . Tymczasem poeci

37 „Gazeta Warszawska” 1826, 15, s. 1.

38 „Dziennik Wileński. Nowiny Naukowe” 1826, 1, s. 18-19. Por. „Kurier Warszawski" 1826,20 , s. 1.

39 „Gazeta Warszawska” 1826, 23, s. 1.

40 „Rozmaitości. Pismo dodatkowe do Gazety Lwowskiej” 1832, 25, s. 18.

${ }^{41}$ W. Bruchnalski, Staszic w poetycznych epicedjach warszawskich 1826 r., w: Stanisław Staszic 1755-1826. Księga zbiorowa, s. 384. 
znajdywali inne uzasadnienia przedstawiania Staszica jako filantropa. Jego dobroczynne dokonania miały $\mathrm{w}$ ich retoryce wiązać się z motywacjami patriotycznymi, co podwójnie uszlachetniało postać. I tak np. Jan Nepomucen Leszczyński w swoim wierszu łączył „dobro Ludzkości” z „miłością kraju świętą” w jedną wartość, mającą inspirować Staszica do nadludzkich wysiłków ${ }^{42}$, a Konstanty Gaszyński opisywał narodowy charakter żalu po stracie wielkiego dobroczyńcy ${ }^{43}$. Jako patriota-filantrop w oczach poetów stał się on postacią monumentalną. Leszczyński kreował Staszica na „nadludzką postać”, wcielenie uniwersalnych wartości czy też rodzaj świeckiego świętego, który miał tylko przypominać zwyczajną osobę: „to nie człowiek - raczej człowieka pozory” ${ }^{4}$. Franciszek Gąsiorowski dostrzegał kontrast tej postaci wobec uwielbianych wcześniej bohaterów-wojowników i przekonywał o równej albo też większej słuszności wysławiania $\mathrm{w}$ podobny sposób pokojowego filantropa, pisząc:

Wierzajcie mi Ziomkowie, nie samym orężem Można zyskać szacunek, i być wielkim mężem.

Dziś powiedzcie, pomniawszy na chwałę STASZICA:

„Zarówno ludzi cnota, jak męstwo zaszczyca, Gdy łzy wyciska wstępne męstwo bohatera Wówczas ręka litości biednym łzy ociera, Można i tutaj zyskać nieśmiertelność drugą, Stałością w świętej cnocie, prawdziwą zasługą [--] Takich to mężów ludy uwielbiać powinny, Cóż dla nas większym skarbem, jak mąż dobroczynny?"45

W poezji dominowały więc propozycje rozumienia filantropii jako działalności patriotycznej oraz zaznaczano nowatorski charakter takiego ujęcia. Młodzieńcze elegie stanowiły przedłużenie wątków pojawiających się wcześniej na pogrzebie oraz podczas pochwały Staszica w $1824 \mathrm{r}$. Zaznaczyć trzeba, że scena poetycka stała się polem walki o zawłaszczenie autorytetu filantropa, polem literackich potyczek pomiędzy twórcami, w kolejnych utworach polemizującymi, kto godniej przedstawił zmarłego i czy godzi się wkładać mu w usta własne słowa ${ }^{46}$.

${ }^{42}$ J.N. Leszczyński, Elegija na zgon JW. Stanisława Staszica Ministra Stanu Prezesa Towarzystwa Przyjaciół Nauk, Warszawa 1826.

${ }^{43}$ K. Gaszyński, Wiersz na zgon Stanisława Staszica, Warszawa 1826.

${ }^{44}$ J.N. Leszczyński, op. cit., s. 5-6.

${ }^{45}$ F. Gąsiorowski, Wiersz na zgon Stanisława Staszica, Warszawa 1826, s. 9-10.

${ }^{46}$ B. Szacka, op. cit., s. 239-251. 
Podobnych napięć szukać można już podczas pogrzebu. Często wspomina się o kłótni pomiędzy akademikami a kupcami warszawskimi o to, komu przypadnie zaszczyt przeniesienia trumny do grobu ${ }^{47}$. Podobnie, krytyczny stosunek hierarchów kościelnych do Staszica ze względu na porzucenie przez niego obowiązków duchownego w trakcie ceremonii zamienił się w walkę o przejęcie jego autorytetu. Arcybiskup Skarszewski zażądał, aby ministra pochowano w szatach duchownego, grożąc uniemożliwieniem pogrzebu w przypadku odmowy. Tymczasem Staszic, mimo przyjęcia niższych święceń, przez większość życia nie nosił takiego stroju. Troszcząc się o to, aby „nie wywołać publicznych protestów” widokiem przebranego ciała, generał Zajączek kazał zaplombować trumnę. Jak komentowali zdarzenie współcześni, „duchowieństwo, przyznając się do niego, zaszczytu nabyło"48 - najwyraźniej więc Kościołowi opłacało się zabiegać o przedstawienie go jako duchownego ${ }^{49}$.

Zespolenie Staszica filantropa i Staszica patrioty w jeden symbol przetrwało długo po pochodzie pogrzebowym. Podtrzymywały je środowiska studencko-akademickie związane z antyzaborczą opozycją. Do września 1826 r. obserwowano zgromadzenia przy grobie Staszica, z których najliczniejsze liczyły nawet do 500 osób. Na murze w okolicach grobu wielokrotnie wypisywano wiersze i hasła patriotyczne, regularnie zamazywane przez księży opiekujących się cmentarzem. W wielu z nich pojawiały się filantropijne motywy „szczęścia Ludzkości” oraz pamięci

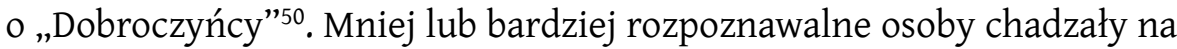
grób w grupie lub samotnie, nawet jeżeli osobiście nie znały zmarłego ${ }^{51}$.

Tak rozumiany autorytet filantropa przetrwał nawet do powstania listopadowego. Większość egzemplarzy Rodu ludzkiego, poematu autorstwa Staszica, została zarekwirowana wkrótce po jego wydaniu przez władze miasta. W nawiązaniu do tego wydarzenia, Jan Olrych Szaniecki zwrócił się do studentów z poniższą odezwą:

Już drugi tydzień naród cieszy się wolnością, a Ród ludzki dotąd jęczy w niewoli. Młodzieży akademicka! Muz wychowańcy! Do was należy uwolnić go z więzów. Zanieście żądanie do Obywatelskiej Rady municypalnej, a ona wyśledzi bez wątpienia miejsce, gdzie jest zamknięty. Ucieszcie czynem tym cienie nieśmiertelnego i dobroczynnego [wyróżnienie - A.W.]

\footnotetext{
${ }^{47}$ Np. T. Lipiński, op. cit., s. 21.

${ }^{48}$ K. Koźmian, Pamiętniki, s. 252.

${ }^{49}$ Zob. T. Lipiński, op. cit., s. 19.

50 S. Małachowski-Łempicki, Pozgonna cześć Staszica, w: Stanisław Staszic 1755-1826. Księga zbiorowa, s. 385-388.

${ }^{51}$ Częściową listę za raportami policji podaje B. Szacka, op. cit., s. 251-254.
} 
Staszica, gdy ulubione dzieło jego, tak wielkiej wagi, Ród ludzki, w należnym tryumfie do biblioteki Towarzystwa Przyjaciół Nauk, skąd zostało zabrane, odprowadzicie ${ }^{52}$.

Ten dobór przymiotników wydaje się niezwykle znaczący. Szaniecki, starając się zdobyć uwagę ogarniętej patriotycznym entuzjazmem młodzieży, powoływał się na wizerunek Staszica jako dobroczyńcy. Jest to jeden z wyraźniejszych dowodów, że to właśnie uznanie wybitnych zasług ministra na polu filantropii było najbardziej naturalne dla mieszkańca Warszawy lat dwudziestych XIX w. Dla młodzieży akademickiej i elity stolicy Staszic był nieśmiertelny dzięki swojej dobroczynności.

W kolejnych latach wokół osoby Staszica narosła legenda, przejawiająca się w opowieściach i anegdotach, czyli najpowszechniejszym sposobie przekazywania informacji. Wiele $\mathrm{z}$ nich publikowanych było $\mathrm{w}$ formie krótkich not w popularnych gazetach, sporo znamy też obecnie dzięki zapiskom pamiętnikarskim ${ }^{53}$. Znaczna część takich opowieści przedstawiała ministra jako wyrozumiałego i pochylającego się nad ubogimi filantropa, który jedynie z zewnątrz wydaje się być surowy i nieprzystępny, co wpisywało się w obraz postaci znany z publicznych mów oraz pogrzebowych elegii. Dzięki anegdotom przekazywanym z ust do ust, wizerunek Staszica zaczął funkcjonować w znacznie szerszej przestrzeni społecznej, był w stanie dotrzeć również do osób niepiśmiennych ${ }^{54}$.

Powyższe wnioski warto podsumować. Staszic został publicznie rozpoznany jako filantrop na posiedzeniach Towarzystwa Przyjaciół Nauk oraz w pracach jego członków, którzy traktowali go jako swoistego idola. TPN grało rolę $w$ rozpowszechnieniu tego wizerunku także później, w szczególności na jego pogrzebie. Dominującymi tematami wiązanymi ze Staszicem był patriotyzm oraz filantropia, gdzie szczególnie czynną grupą była młodzież akademicka, będąca również pod wpływem TPN.

${ }^{52}$ Za: A. Kraushar, Towarzystwo Warszawskie Przyjaciót Nauk 1800-1832. Monografia historyczna osnuta na źródłach archiwalnych, ks. 4: Czasy polistopadowe. Epilog. 1831-1836, Kraków-Warszawa 1906, s. 20.

${ }^{53}$ Istnieją liczne przykłady powszechnie znanych anegdot o Staszicu filantropie, np.: „Kurier Warszawski” 1826, 42, s. 1-2; „Rozmaitości Lwowskie” 1826, 15, s. 9; Stanisław Staszic, „Przyjaciel Dzieci” 1865, 3, s. 33-37; seria Stanisław Staszyc, „Niepodległość" 1 , 1866, 6, s. 1; 7, s. 2; 18, s. 2-3.

${ }^{54}$ Wiejskie piosenki wspominające o Staszicu: Hrubieszanin o Staszicu, w: S. Bratkowski, Pieśni narodowe i sielanki, Warszawa 1827, s. 14-15; Zacnej Duszy w Bogu spoczywajacego Stanisława Staszica, dobroczyńcy, i za potwierdzeniem Rządowem Ustawodawcy swych włościan majątności Hrubieszowa, do czterech tysięcy mieszkańców uszczęśliwiającej, w: Piosnki wieśniacze znad Niemna i Dźwiny, niektóre przysłowia i idiotyzmy, w mowie Sławiano-Krewickiej, s postrzeżeniami nad nią oczynionemi, [J. Czeczot], Wilno 1846, s. 1-2. 
Odróżniano go przy tym od wcześniejszych dobroczyńców. Bardziej nawet niż na jego czynach, skupiano się na samej postaci Staszica, traktowanej jako wzór osobowy. Szersze warstwy społeczne dowiadywały się o filantropie poprzez narzędzia „masowego” przekazu, takie jak prasa, wiersze oraz anegdoty. Śmierć przekreśliła kontrowersje, które wcześniej wiązano z osobą ministra, a jego wizerunek zaczął być obiektem sporów pomiędzy różnymi grupami społecznymi.

\section{Część 2. Pogłębiony kontekst wysławienia Staszica}

Badanie zjawisk takich jak sława nie może ograniczyć się do analizy faktów związanych z postacią, której się ją przypisuje. Nie jest ona bowiem jedynym aktorem procesu budowania sławy. Równie istotne co ona są instytucje pośredniczące oraz grupy społeczne stanowiące odbiorców jej wizerunku. Konieczne jest więc przybliżenie okoliczności, w jakich Staszic nabył swój szczególny status. Poniżej skupiam się na głębszej kontekstualizacji i przedstawieniu procesów, które mogły mieć znaczący wpływ na społeczeństwo polskie oraz środowiska związane z omawianym zjawiskiem. Zdecydowałem się odnieść do trzech płaszczyzn: historii idei, historii społecznej oraz historii kulturowej, w tym konkretnym wypadku przedstawionych przez opis przemian myśli filantropijnej, sytuacji historycznej społeczeństwa polskiego oraz transformacji charakteru sławy, które obserwować można od drugiej połowy XVIII stulecia do lat dwudziestych XIX w. Opis ten ma na celu ukazanie popularności Staszica jako fenomenu odzwierciedlającego szersze zmiany struktur społecznych ziem polskich tego okresu.

\section{Przemiany w europejskiej i polskiej filantropii końca XVIII i początku XIX wieku}

Nowoczesną filantropię definiować można jako prywatną, zorganizowaną formę opieki nad potrzebującymi, motywowaną wartościami humanitarnymi lub narodowymi. Jej historia zaczyna się w Anglii drugiej połowy XVIII w., wraz z rozwojem gospodarki kapitalistycznej, dzięki której pojawiło się piśmiennictwo naukowe skupione na problematyce produkcji, podziału i wymiany zasobów w ramach społeczeństwa. Obok narodzin dziedziny ekonomii politycznej, przemiany te przyniosły wzrost liczby publikacji poświęconych tematyce ubóstwa. Działo się to w ścisłym związku z praktyką społeczną, w ramach której reformatorzy, związani ze 
środowiskami naukowców, lekarzy, prawników i polityków, zaczęli angażować się w szeroko pojętą działalność na rzecz ubogich. Wartością było dla nich dobro publiczne, co odróżniało ich poczynania od znanych wcześniej form dobroczynności, takich jak mecenat nad sztuką czy chrześcijańska charytatywność. Nowe trendy filantropii promieniowały z Wysp Brytyjskich na kontynent, gdzie docierały z pewnym opóźnieniem.

Na ziemiach polskich rozwój podobnej formy działalności charytatywnej przypada na początek wieku XIX. Chociaż dyskusje dotyczące opieki społecznej miały miejsce już za czasów Sejmu Wielkiego ${ }^{55}$, szansa na podjęcie takich inicjatyw pojawiła się dopiero wraz ze stworzeniem przez Napoleona Księstwa Warszawskiego w 1807 r. oraz po wojnach napoleońskich, w istniejącym od 1815 r. konstytucyjnym Królestwie Polskim. Nowi polscy filantropi wywodzili się ze środowisk skupionych wokół uniwersytetów, czasopism oraz towarzystw dobroczynnych pozostających pod dużym wpływem idei oświeceniowych. Ich koncentracja w ośrodkach miejskich miała swoje korzenie w rosnących potrzebach urbanizującego się społeczeństwa. Czynnikiem mającym decydujący wpływ na kształt polskiej filantropii był kosmopolityzm dobroczyńców, wcale niewykluczający motywacji patriotycznej. Pozostawali oni w stałym kontakcie ze światem ogólnoeuropejskiej filantropii, często utożsamiając się z uniwersalistycznymi wartościami tego środowiska. Związki te podtrzymywane były dzięki coraz popularniejszym podróżom zagranicznym, lekturze dzieł obcych, a także przynależności do lóż wolnomularskich, których członkowie zobowiązani byli do humanitarnych wysiłków ${ }^{56}$.

Nawiązując do oświeceniowego pojmowania filantropii, nowa dobroczynność zrywała ideową ciągłość z długowiekową tradycją charytatywności chrześcijańskiej opartej na zasadach wiary. Nowe trendy wiązały dobroczynność z nauką, humanitaryzmem, utylitaryzmem i sferą świecką. Bronisław Geremek widział przyczyny tych zmian w spadającym od XVII w. znaczeniu motywacji etycznych i religijnych w działalności dobroczynnej oraz w rozwoju myśli ekonomicznej, przenoszącej problem ubóstwa do sfer polityki społecznej, interesu zbiorowości i racji stanu. Toczone na przełomie XVIII i XIX w. kampanie polityczne

${ }^{5}$ Zob. M. Maludzińska, „Kraj jest nieszczęśliwy, że ma ludzi próżnujących”. Walka z ubóstwem $w$ Warszawie na tle sytuacji społeczno-gospodarczej Rzeczypospolitej w dyskursie publicystycznym drugiej połowy XVIII wieku, Warszawa 2015.

${ }^{56}$ Najlepsze omówienia tej przemiany znajdują się w: E. Mazur, Dobroczynność w Warszawie XIX wieku, Warszawa 1999, s. 20-25; E. Leś, Zarys historii dobroczynności i filantropii w Polsce, Warszawa 2001, s. 17-19; C. Kępski, Idea miłosierdzia a dobroczynność i opieka, Lublin 2002, s. 3-12; M. Piotrowska-Marchewa, Nędzarze i filantropi. Problem ubóstwa w polskiej opinii publicznej w latach 1815-1863, Toruń 2004, s. 255-259. 
i publicystyczne o tolerancję religijną, zniesienie poddaństwa chłopstwa, reformę więzień oraz abolicję niewolnictwa realizowały w praktyce koncepcję przeniesienia działalności filantropijnej do sfery świeckiej. Innymi słowy, miłość bliźniego przechodziła swoistą laicyzację ${ }^{57}$. Za różnicami pomiędzy starym i nowym projektem dobroczynnym szły odmienności terminologiczne, utrudnione dziś w odczycie przez współczesne, szerokie rozumienie pojęcia „filantropia”. „Zamiast charité pojawiło się bienfaisance, zamiast Mildkeit - Mildtätigkeit, zamiast charity - beneficence, czyli dobroczynność, filantropia, pojęcie etymologicznie związane z miłością człowieka, w żywych językach przełożone na działanie", jak pisała o tym Zofia Podgórska-Klawe ${ }^{58}$. W Polsce, historyczna praktyka w używaniu terminów takich jak „miłosierdzie”, „działalność charytatywna” czy „filantropia religijna” w odniesieniu do dobroczynności religijnej, opartej na miłości do bliźniego w sensie religijnym (charitas), odróżniała je od haseł „filantropia” bądź „dobroczynność świecka”, odwołujących się do humanitaryzmu i oświeceniowej „miłości do człowieka” (philanthrōpia) ${ }^{59}$. Zupełnie niezależnie od tego, że wielu hierarchów kościelnych współdziałało z filantropami, w opinii publicznej pierwszej połowy XIX w. zarysowywał się konflikt pomiędzy dobroczynnością świecką i religijną ${ }^{60}$.

Nowe idee, na których opierała się filantropia, szły w parze z nowymi wartościami, które uczyniły ją popularną. Humanitaryzm był jednym z najsilniejszych środków wyrazu filozofii oświeceniowej i przez cały wiek XVIII w coraz większym stopniu przenikał do powszechnej świadomości zarówno w Europie, jak i w Polsce. Doprowadziło to do przełomowych zmian w rzeczywistości społecznej i politycznej, czasami będących efektem działalności ambitnej jednostki, jak reformy Johanna Friedricha Struenseego w Danii, a czasami reakcją na nastroje ludu, którą była np. decyzja władz Londynu o porzuceniu wykonywania egzekucji na słynnym wzgórzu Tyburn ${ }^{61}$. Znaczący wpływ na popularność filantropii miał jej uniwersalny charakter. Społecznicy czerpali z tradycji oświeceniowej

57 B. Geremek, Litość i szubienica. Dzieje nędzy i miłosierdzia, Warszawa 1989, s. 289. Nie oznacza to jednak, że do towarzystw dobroczynnych nie przystępowano z pobudek religijnych.

58 Z. Podgórska-Klawe, Od hospicjum do współczesnego szpitala. Rozwój problematyki szpitalnej w Polsce do końca XIX wieku, Wrocław 1981, s. 21.

$59 \mathrm{~W}$ dzisiejszych definicjach słownikowych filantropia rozumiana jest znacznie szerzej oraz towarzyszy jej konotacja pejoratywna, „szczodrobliwość na pokaz”. Szersze omówienie kwestii terminologicznych w: M. Piotrowska-Marchewa, op. cit., s. 73-83.

${ }^{60}$ Ibidem, s. 81-82.

${ }^{61}$ S. Devereaux, Recasting the Theatre of Execution. The Abolition of the Tyburn Ritual, „Past \& Present” 202, 2009, 1, s. 127-174. 
ściśle skorelowanej z naukowym obiektywizmem i bezstronnością, postulatem tolerancji religijnej oraz wpływem wielkich rewolucji wieku XVIII, amerykańskiej i francuskiej, będącymi próbami wcielenia w życie zasady równości obywatelskiej. Wszystkie te prądy myślowe zakładały egalitaryzm znoszący wiele wcześniej żywotnych podziałów. W rezultacie filantropi wytworzyli uniwersalną retorykę „pracy dla dobra ludzkości”, nawet jeśli poświęcali się działalności lokalnej, zwykle skupiając się na własnym $\mathrm{kraju}^{62}$. W okresie wzrostu napięć i nierówności społecznych reprezentanci najbardziej inkluzywnej ideologii, która przynosiła faktyczne rezultaty, byli ikonami silnie przemawiającymi do wyobraźni zubożałych współobywateli ${ }^{63}$. W końcu, jak dostrzega Amanda Moniz, w mentalności ludzi przełomu XVIII i XIX w. filantropia rozumiana była jako forma działalności patriotycznej, często alternatywna dla walki zbrojnej ${ }^{64}$. W ten sposób mieli widzieć ją Brytyjczycy działający dla dobra swojego Imperium od Ameryki po Indie (np. John Howard, Henry Moyes, Robert Owen), Francuzi zaangażowani w ochronę prześladowanych za czasów Terroru (np. Jean Baptiste Antoine Auget de Montyon), pietyści niemieccy starający się zapewnić nowe źródła utrzymania mieszkańcom najuboższych wiosek Europy Środkowej (Hans Ernst von Kottwitz czy Jean Frederic Oberlin), a także dobroczyńcy czynni na ziemiach polskich.

W coraz większym stopniu jako dobroczyńcy wychwalani byli lokalni aktywiści związani z warstwą mieszczańsko-szlachecką, a coraz rzadziej członkowie środowisk arystokratycznych i kościelnych, reprezentanci tradycyjnie rozumianej charytatywności oraz układu społecznego przywodzącego na myśl ancien régime. Oddzielono mecenat i filantropię religijną od figury nowoczesnego dobroczyńcy. W oderwaniu od znanego dotychczas zaplecza ideologicznego, które przekierowywało wdzięczność za wsparcie na instytucję Kościoła, filantropi byli nią obdarzani jako jednostki. Okres wzrostu tendencji równościowych i rosnącej urbanizacji, w którym zwrócono szczególną uwagę na majątkowe nierówności społeczne, jeszcze bardziej przyczyniał się do nadania szczególnego statusu tym, którzy starali się je zmniejszyć w imię uniwersalnych wartości

${ }^{62} \mathrm{~W}$ zachodnich pracach poświęconych filantropii zwraca się uwagę na tę pozorną sprzeczność. Patrz: A. Moniz, From Empire to Humanity. American Revolution and the Origins of Humanitarianism, Oxford 2016, s. 4-11, 156-168.

${ }^{63}$ Przykładami takich ikonicznych postaci byli m.in. John Howard, Jean Frederic Oberlin czy Henry Moyes, zob. G. Cervantes, D. Porter, Extreme Empiricism. John Howard, Poetry, and the Thermometrics of Reform, „The Eighteenth Century” 57, 2016, 1, s. 95-119; A. Moniz, op. cit., s. 110-129. Por. D. Andrew, Philanthropy and Police. London Charity in the Eighteenth Century, Princeton 2014, s. 146-154.

64 A. Moniz, op. cit., s. 157-159. 
humanitarnych. Ten symboliczny kapitał popychał naprzód „profesjonalizację" i przyczynił się do wyodrębnienia społecznej funkcji filantropa. W końcu zaczęły pojawiać się osoby, dla których filantropia była głównym zajęciem (tzw. full-time philanthropists ${ }^{65}$ ).

Przemiany związane ze skrystalizowaniem się świeckiej formy filantropii skorelowanej ze zmianami społecznej wrażliwości oraz przeciwstawianej chrześcijańskiej charytatywności stanowiły jeden z elementów konstytuujących proces budowania sławy Staszica. Zwrócenie na nie uwagi pozwala zrozumieć, dlaczego to właśnie on, a nie filantropi motywowani religijnie (jak np. Jakub Falkowski, pijar oraz założyciel Warszawskiego Instytutu Głuchoniemych, dziś kojarzony z pojęciem filantropii o wiele częściej niż Staszic), znaleźli się w centrum uwagi publicznej.

\section{Przemiany w rzeczywistości społeczno-politycznej ziem polskich początków XIX wieku}

Filantropi działali w reakcji na narastające potrzeby polskiego społeczeństwa. Wraz z początkiem industrializacji ziem polskich pojawił się problem skrajnej nędzy, szczególnie dostrzegalnej na zaniedbanej wsi oraz wśród biedoty miejskiej. Sytuację zaostrzała migracja do miast, nieproporcjonalnie wysoka $\mathrm{w}$ stosunku do tempa powstawania nowych miejsc pracy oraz obciążona brakiem kwalifikacji przenoszącej się ludności, zwiększona w konsekwencji zniesienia poddaństwa chłopstwa przez dekret grudniowy z $1807 \mathrm{r}^{66}$ Postępującej pauperyzacji sprzyjało szerzenie się chorób zakaźnych i epidemii oraz kryzysowa sytuacja rolnictwa polskiego. Tragiczniejszym skutkiem kampanii napoleońskich było wyniszczenie ziem polskich oraz ogromna liczba kalek, sierot i wdów, których utrzymanie po wojnach spadało na społeczeństwo ${ }^{67}$. Tu zatem leżała bezpośrednia przyczyna powszechnej sympatii wobec filantropów - istniało na nich realne zapotrzebowanie.

Społeczeństwo przechodziło również wiele przemian związanych ze sferą zbiorowej wyobraźni. Zmieniała się kompozycja, status i wzajemne relacje poszczególnych grup społecznych. Na kształt stosunków pomiędzy nimi wpłynęło zaadaptowanie do systemu prawnego Księstwa

65 O znaczeniu zajmowania się filantropią „na pełen etat” pisała Gertrude Himmelfarb w The Roads to Modernity. The British, French, and American Enlightenments, New York 2008, s. 132-135.

${ }^{66}$ A. Jezierski, C. Leszczyńska, Historia gospodarcza Polski, Warszawa 1997, s. 112-114, 156-164; T. Kizwalter, Historia powszechna. Wiek XIX, Warszawa 2007, s. 11-13.

${ }^{67}$ J. Kaliński, Historia gospodarcza XIX i XX w., Warszawa 2004, s. 41-44. 
Warszawskiego w 1807 r., a następnie Królestwa Polskiego w 1815 r. postanowień Kodeksu Napoleona, który w sposób rewolucyjny w historii ziem polskich rozszerzał prawa obywatelskie i wyborcze ${ }^{68}$. Zyskanie przez warstwy mieszczańskie kompetencji politycznych i umożliwienie im awansu w ramach struktur administracji państwa przyczyniło się do poszukiwania przez te grupy nowych wartości związanych ze wzbogaceniem ich tożsamości grupowej. Odnaleziono je w stabilnym rozwoju, docenieniu oszczędności i pracy, praktyczności i współczuciu, krystalizowanych w postawach filantropijnych ${ }^{69}$. Szczególnym wyrazem takiej postawy były różne formy samopomocy, będące jednym ze źródeł formuły towarzystw dobroczynnych ${ }^{70}$. Upodmiotowienie mieszczaństwa nabierało dynamiki razem z przemianami demograficznymi - zwiększeniem się populacji kraju związanym z rozwojem cywilizacyjnym oraz przyspieszoną migracją do miast. Fakt, że szersze warstwy społeczeństwa zaczęły brać czynny udział w sprawach ważnych dla państwa, zmuszał do przedefiniowania relacji jednostka-państwo. Zmienił się sposób, w jaki percypowany był obowiązek obywatelski. Znana z niezależnej Rzeczypospolitej koncepcja narodu politycznego ograniczonego do szlachty wypierana była przez idee powszechnego obywatelstwa rozumianego w duchu Kodeksu Napoleona oraz nowego patriotyzmu, podkreślającego znaczenie narodu rozumianego jako grupa etniczna ${ }^{71}$. W tych okolicznościach zaczęły zachodzić przemiany związane ze zbiorową tożsamością społeczeństwa polskiego. Po burzliwym okresie przyzwyczajania się do rzeczywistości porozbiorowej, powstania kościuszkowskiego oraz wojen napoleońskich, musiało ono na nowo określić się jako zbiorowość ${ }^{72}$.

Warto w tym momencie zatrzymać się i przyjrzeć teorii społecznej dotyczącej tego zagadnienia. Autorytet w dziedzinie zmiany społecznej, Shmuel Eisenstadt, twierdził, że „tworzenie zbiorowości i zbiorowych

${ }^{68}$ Więcej: Z. Kowalewski, Społeczeństwo obywatelskie $w$ doświadczeniu historycznym, Warszawa 1991, s. 85-289; J. Bardach, Naród polityczny i jego przemiany (1493-1993), w: Społeczeństwo obywatelskie i jego reprezentacja (1493-1993), red. idem, Warszawa 1995, s. 5-19.

69 O transformacjach wartości mieszczańskich mówi zbyt rzadko wykorzystywana w badaniach historycznych praca Marii Ossowskiej, Moralność mieszczańska, Wrocław 1985.

${ }^{70}$ M. Wawrzyński, Samopomoc i samoorganizacja Polaków od XIX do XXI wieku, Toruń 2007, s. 108-119.

${ }^{71}$ W.J. Burszta, J. Nowak, K. Wawruch, Od narodu szlacheckiego do państwa narodowego, w: Polska refleksja nad narodem. Wybór tekstów, red. iidem, Poznań 2002, s. 9-14; J. Nowak, Duchowe piętno społeczeństw. Złożoność i przeobrażenia polskiej refleksji nad narodem w XIX wieku, Warszawa 2008, s. 35-40, 101-105.

${ }^{72}$ Zmiany te noszą znamiona rozpoznane również przez teorię społeczną, zob. T. Paleczny, Socjologia tożsamości, Kraków 2008, s. 105-106, 129-131. 
tożsamości obejmuje wyliczenie specyficznych atrybutów tych zbiorowości w odniesieniu do [--] specyficznego programu kulturowego - oraz ich konkretyzację w określonym miejscu i czasie"73. Następnie wiązał ten proces z kształtowaniem typów ludzkich i wzorców zachowania, które oddawać mają „atrybuty podobieństwa” członków danej zbiorowości. Wzorce, w odróżnieniu od modeli, noszą silnie pozytywną konotację i odnoszą się do „sfery sacrum lub transcendencji”74. Innymi słowy, w trakcie przebudowy swojej zbiorowej tożsamości, społeczności wskazują na wzory zachowań, które jednocześnie wyrażają charakterystyczne cechy wspólnoty, jak i reprezentują zalety, na których ogniskuje się przyjmowany przez wspólnotę program kulturowy. Ta dwoistość funkcji opisywana była wcześniej przy okazji omawiania wzorów osobowych przez Marię Ossowską ${ }^{75}$. Według Eisenstadta nie wystarcza, aby wspomniane wzorce były dostrzegane i poddane publicznej, intelektualnej czy artystycznej dyskusji, muszą być też manifestowane, szczególnie za pomocą „rytuałów upamiętniających i publicznych ceremonii”, w celu stworzenia silnych symboli i instytucjonalizacji zbiorowych wartości ${ }^{76}$.

Koncepcja Eisenstadta wydaje się znakomicie stosowalna do opisu kultu filantropa, wyrażonego w uwielbieniu postaci Staszica. W jej myśl, kult ten, będący próbą poszukiwania nie tyle nowych bohaterów, co nowego typu herosów, był wyrazem samookreślenia się społeczeństwa polskiego po kryzysie tożsamości narodowej, który nadszedł na przełomie XVIII i XIX w. ${ }^{77}$ Co więcej, powiązany był ze wzorcem osobowym, w którym opinia publiczna upatrywała odpowiedniego reprezentanta nowoczesnych wartości narodowo-obywatelskich. Takim wzorem był filantrop, ponieważ zawierał w sobie aspekt działalności patriotycznej, realizację mieszczańskich dążeń do pokojowego rozwoju ekonomicznego oraz odniesienie do sfery sacrum/transcendencji, w tym wypadku konkretyzowanej w ideale humanitarnym. Warto podkreślić, że filantrop

73 S. Eisenstadt, Programy kulturowe, budowanie tożsamości zbiorowych i nieustajaca rekonstrukcja pierwotności, w: idem, Utopia i nowoczesność. Porównawcza analiza cywilizacji, Warszawa 2011, s. 53.

74 Ibidem, s. 61-62.

${ }^{75}$ M. Ossowska, Pojęcie wzoru i pojęcie naśladownictwa, w: eadem, Ethos rycerski i jego odmiany, Warszawa 2000, s. 9-21.

76 S. Eisenstadt, op. cit., s. 66-67.

77 O kryzysie tożsamości narodowej obszerniej np. J. Nowak, Naród i narodowość w polskiej myśli romantycznej, w: Naród-Tożsamość-Kultura. Między koniecznością a wyborem, red. W.J. Burszta, K. Jaskułowski, J. Nowak, Warszawa 2005, s. 201-212; J. Czubaty, Zasada „ dwóch sumień". Normy postępowania i granice kompromisu politycznego Polaków w sytuacjach wyboru (1795-1815), Warszawa 2005, s. 660-664; A. Nowak, Polski patriotyzm wieku niewoli: trzy formuły?, w: Patriotyzm Polaków. Studia z historii idei, red. J. Kloczkowski, Kraków 2006, s. 73-94. 
mógł być atrakcyjnym wzorcem, ponieważ miał potencjał reprezentować pozornie sprzeczne interesy: cnoty mieszczańskie ze szlacheckimi (postęp ekonomiczny i rycerskie pochylanie się nad słabszym) oraz świecką dobroczynność wraz z motywacjami religijnymi. Jak pisał Eisenstadt, wyróżnione w ten sposób wzorce zawierają w sobie „pewien pluralizm kolektywnych tożsamości i typów ludzkich, a także zmagania między jej konkurencyjnymi konstrukcjami i wykładniami”, prowadząc często do ostrej konkurencji pomiędzy aktorami społecznymi, którzy chcą narzucić swoją interpretację budowanemu zbiorowo symbolowi ${ }^{78}$. Ambiwalencja interpretacji postaci filantropa przejawiała się podczas pogrzebu Staszica, kiedy platformę dla wyrażenia swoich wizji patriotyzmu znajdowały zarówno środowiska dążące do gospodarczego odrodzenia kraju, jak i te, dla których najważniejsze było odzyskanie niepodległości na drodze walki zbrojnej. W dobroczyńcy dostrzegano alternatywę dla bohaterów-wojowników takich jak Kościuszko czy książę Poniatowski. Konieczność odnalezienia takiego wariantu dyktowana była z jednej strony sympatią wobec konsensusowych rozwiązań napięć polsko-rosyjskich, która narastała od nieudanych prób stworzenia w pełni niezależnego państwa za czasów napoleońskich ${ }^{79}$, a z drugiej kryzysem tożsamości narodowej, który spowodował zerwanie transmisji wzorca rycerskiego, niesionego przez szlachtę ${ }^{80}$. Niezależnie od tego, że model filantropa był wiązany raczej z pokojowymi reformami niż tendencjami powstańczymi, mógł on być również przeciwstawiany centralizmowi państwowemu i stanowić oddolny instrument zabezpieczający polski interes narodowy w obliczu władzy zaborczej (w przypadku Staszica działo się tak w szczególności podczas powstania i w latach trzydziestych).

Można wskazać również na środowiska bezpośrednio zaangażowane w promocję takich wzorców i w przygotowywanie podatnego gruntu społeczno-kulturowego pod sławę nowych herosów. W Warszawie takim centrum było otoczenie Towarzystwa Przyjaciół Nauk, poświęcające się m.in. działalności, którą współczesna pedagogika nazywała „społecznymi wzmocnieniami pozytywnymi" - wskazywaniem wzorcowych zachowań poprzez stawianie pomników, gromadzenie rzeźb i obrazów, lansowanie twórczości artystycznej czy literackiej oraz nadawanie honorowego członkostwa (choć tu równie wiele nadań koniunkturalnych) ${ }^{81}$.

78 S. Eisenstadt, op. cit., s. 69-70.

79 J. Czubaty, Zasada „dwóch sumieñ”, s. 677-680.

${ }^{80}$ M. Ossowska, Moralność mieszczańska, s. 312-333.

81 A. Wojda, Konstruktorzy pamięci. O etosie heroicznym $w$ „Śpiewach historycznych” Juliana Ursyna Niemcewicza, w: Prace Herkulesa. Człowiek wobec wyzwań, prób i przeciwności, red. M. Cieśla-Korytowska, O. Płaszczewska, Kraków 2012, s. 127-148. 
Sam Staszic był szczególnie aktywny w tej mierze, kiedy jako prezes Towarzystwa naciskał na udostępnianie publiczności biblioteki i niektórych gabinetów włącznie z bogatymi wystawami oraz poprzez ufundowanie słynnego pomnika Kopernika ${ }^{82}$. Autorytet elity „kulturotwórczej”, jaki zyskali sobie członkowie Towarzystwa, dawał o sobie wyraźnie znać podczas powstania listopadowego, kiedy przypisywano im role przywódcze ${ }^{83}$. Co więcej, środowisko to było dobrze zaznajomione nie tylko z przykładami heroizacji zagranicznych filantropów, ale również z kulturą celebrycką, jaka ich otaczała. Julian Niemcewicz wspomina o najsłynniejszym przykładzie, Johnie Howardzie (,ten czynny i niespracowany przyjaciel Człowieka"), w swojej pracy 0 więzieniach publicznych z roku 1818 i przytacza tłumaczenie słynnej mowy Edmunda Burke’a, w której ten chwalił dokonania angielskiego filantropa. „Pochwała Howarda, przez jednego z najwymowniejszych Mężów wieku naszego, nie może być powtarzaną zbyt często" - komentował Niemcewicz, wskazując na to, że mowa Burke'a znana była wśród zainteresowanych ${ }^{84}$. Inny członek Towarzystwa, Krystyn Lach-Szyrma, w swoich pamiętnikach z podróży do Anglii i Szkocji również wzmiankował o Howardzie, pisząc o nim „nieśmiertelny i pełen ludzkości" ${ }^{35}$. Źródłem wstępnego zapoznania się z zagranicznymi gwiazdami filantropii była prasa wspominająca o Howardzie, a także Oberlinie i Owenie coraz częściej od wczesnych lat dwudziestych ${ }^{86}$. Możliwe, że do środowisk intelektualnych, bardziej mobilnych międzynarodowo i kompetentnych lingwistycznie, sława tych postaci docierała już wcześniej. TPN posiadało więc zarówno kapitał symboliczny, czyli poziom uznania społecznego, jak i wzorce potrzebne do tworzenia nowych bohaterów.

82 P. Wątroba, Stanisława Staszica siedziby Towarzystwa Królewskiego Przyjaciół Nauk w Warszawie. Rys historyczno-architektoniczny, „Wiek Oświecenia” 22, 2006 („Stanisław Staszic - myśliciel, pisarz, uczony"), s. 118-121.

83 A. Kraushar, Towarzystwo Warszawskie Przyjaciół Nauk, ks. 4, s. 14-19.

${ }^{84}$ J.U. Niemcewicz, O więzieniach publicznych czyli domach pokuty rzecz krótka, Warszawa 1818, s. 9-11.

${ }^{85}$ K. Lach-Szyrma, Anglia i Szkocja. Przypomnienia z podróży roku 1820-1824 odbytej, wyd. P. Hertz, Warszawa 1981, s. 380.

${ }^{86}$ Notki prasowe dotyczące Oberlina: „Kurier Warszawski” 1829, 256, s. 2; „Pamiętnik Warszawski Umiejętności” 1829, 9, s. 1; „Gazeta Polska” 1829, 299, s. 1; dotyczące Howarda: „Dzieye dobroczynności krajowey i zagraniczney z wiadomościami ku wydoskonaleniu jey służącemi" 2, 1821, s. 2130-2146. Prasa polska czasami zajmowała się też innymi słynnymi filantropami, np. Robertem Owenem, a słynna praca barona Josepha Marie de Gerando, Opiekun ubogich, która wyznaczała miejsce filantropa w społeczeństwie, wydana była po polsku już w roku 1822. 


\section{Przemiana charakteru sławy}

Dostrzeżenie znaczenia, jakiego nabrała świecka filantropia, oraz faktu, że po wojnach napoleońskich społeczeństwo polskie zwróciło się w stronę restrukturyzacji swojej zbiorowej tożsamości, wciąż pozostawia pewne niedopowiedzenia. Dlaczego to wzór osobowy, a nie inny rodzaj wzorca okazał się atrakcyjny dla zmieniającej się tożsamości Polaków? Dlaczego do tej roli wykorzystano znaną osobistość, a nie dawno zmarłych bohaterów ${ }^{87}$ ? Czy Staszic uosabiał inne symbole, prócz społecznie uznanych cnót różnych grup społecznych? Odpowiedzi szukać można w przyjęciu perspektywy studiów nad sławą (celebrity studies), zgodnie z którą od drugiej połowy XVIII w. w Europie, poczynając od Francji i Anglii, zaszła przemiana w sposobie myślenia o sławie, doprowadzając do powstania nowej klasy ludzi sławnych, czyli celebrytów, jak udowadnia w swojej nowatorskiej pracy Antoine Lilti ${ }^{88}$. Grupa ta wyróżniać się miała szczególnie silnym oddziaływaniem na szerokie warstwy społeczne zafascynowane prywatnym życiem takich jednostek; innymi słowy, Lilti poszukuje źródeł problemu „iluzji intymności”, będącego jednym z najwyraźniejszych elementów definiujących celebrytów ${ }^{89}$. „Iluzja intymności” oznacza jednostronne przekonanie o personalnej bliskości w relacji fan-idol, nawet jeżeli obydwie osoby nigdy się ze sobą nie spotkały. Ten dystans przełamywany jest poprzez media, skrupulatnie informujące fanów o szczegółach życia ich idoli. Podczas tego procesu w grę wchodzi również persona - publiczna twarz osób sławnych, odrębna od ich prywatnego „ja” i wyraźnie dostrzegana przez nich samych.

Rozumiejąc, że badanie „celebrytyzmu”, jak możemy nazwać to zjawisko, skupia się przede wszystkim na analizie relacji pomiędzy sławnymi postaciami przedstawianymi przez zróżnicowane media a ich

87 Chociaż na gruncie historiografii próbowano robić i to. Zob. A. Stępnik, Mity w wiązaniu narracji historycznej, „Klio. Czasopismo poświęcone dziejom Polski i powszechnym" 34, 2015, 3, s. 6-18.

${ }^{88}$ A. Lilti, Figures publiques. L'invention de la célébrité (1750-1850), Paris 2014. Świadomie posługuję się tutaj istniejącym już w języku polskim słowem „celebryta” bądź jego angielskim, również bezosobowym, odpowiednikiem (celebrity może oznaczać rodzaj sławy, a nie tylko osobę, która znana jest w taki sposób). Zarówno w języku angielskim, jak i polskim współcześnie przypisuje się pojęciu negatywne znaczenie, jednak w obrębie studiów nad sławą trwają próby odejścia od pejoratywnej konotacji tego słowa poprzez przypisanie mu konkretnej definicji. Próba zastąpienia tego terminu innym byłaby krzywdzącym pominięciem problemu, który może być kluczowy dla zrozumienia całego zagadnienia. Więcej: A. Wesołowski, op. cit.

${ }^{89}$ Por. C. Rojek, op. cit., s. 1-6. 
publicznościami ${ }^{90}$, Lilti wskazuje na społeczno-historyczne przyczyny pojawienia się celebrytów. Źródła nowego zjawiska leżeć miały w osiemnastowiecznym kryzysie ładu społecznego. Erozja struktury klasowo-warstwowej przejawiała się w nowych okazjach awansu społecznego, dzięki którym znani pisarze, artyści i aktorzy mogli przełamać istniejącą hierarchię. Ich status, majątek czy znajomości zależały w coraz większej mierze właśnie od sławy ${ }^{91}$. Rozwój gospodarki kapitalistycznej i rozpowszechnienie zasady suwerenności ludu wpłynęły na zwiększenie znaczenia opinii publicznej ${ }^{92}$. Libertyńska filozofia i romantyczna literatura przyczyniły się do docenienia indywidualizmu i jednostkowej autentyczności. W późnym wieku XVIII mechanizmy „celebrytyzmu” - kreacja i komercjalizacja wizerunku, wszechobecność skandali, fascynacja intymnym życiem publicznych osób - przeniknęły z gwiazd teatru na sferę publiczną w ogóle, a szczególnie na scenę polityczną ${ }^{93}$. Sławne osoby były często obdarzane autorytetem politycznym (np. Jean-Jacques Rousseau czy Voltaire), a postaci ze świata polityki często musiały poświęcać czas na budowanie wizerunku i projekcję autentyczności na pokaz na wzór popularnych pisarzy czy aktorów ${ }^{94}$. Przyjęcie, że Staszic był jedną z takich osób, zgadzałoby się z zachodnimi przykładami filantropów-celebrytów ${ }^{95}$ i wyjaśniałoby kilka istotnych problemów związanych z jego sławą.

Czy Staszic był jednym z celebrytów w sensie, o który chodziło Liltiemu? Istnieją przesłanki do tego, żeby tak sądzić. Pierwszorzędnym argumentem jest fakt, że filantrop był postacią dobrze znaną w Warszawie jeszcze za swojego życia, a jego osobowość była przedmiotem wielu anegdot i dowcipów hiperbolizujących jego wady i zalety. Ta hiperbolizacja nie była przypadkowa, ale podyktowana określoną wizją „publicznej twarzy" (czy też persony) skromnego, uparcie idealistycznego, przez co trudnego w obyciu, oraz całkowicie poświęconego sprawie polskiej dobroczyńcy ${ }^{96}$. Dziwiąc się pogrzebowemu uwielbieniu Staszica, Skarbek

90 Jednym słowem, mówić można o publicité. Lilti poświęcił temu zjawisku znaczną część swojej wcześniejszej pracy, Le monde des salons. Sociabilité et mondanité à Paris au XVIII siècle, Paris 2005.

${ }^{91}$ Korzystam z angielskiego tłumaczenia pracy A. Liltiego, The Invention of Celebrity, 1750-1850, Cambridge 2017, s. 6-11, 24-32.

92 Ibidem, s. 10-11.

93 Ibidem, s. 11-14.

94 Ibidem, s. 137-142.

${ }^{95}$ Np. zagadką dla brytyjskiej historiografii jest sława Howarda, zob. R. Morgan, Divine Philanthropy: John Howard Reconsidered, „History” 62, 1977, 206, s. 388-410.

96 P.D. Marshall, Celebrity and Public Persona, Oxford Bibliographies, www.oxfordbibliographies.com/view/document/obo-9780199756841/obo-9780199756841-0159.xml (dostęp 29 VI 2017). 
nie zastanawiał się, dlaczego filantrop miałby nagle stać się popularny, ale raczej, skąd jego czysto pozytywny odbiór, skoro za życia wzbudzał tyle kontrowersji ${ }^{97}$. Odkładając na bok politykę, zainteresowanie sferą powierzchowności dobroczyńcy: „w skutku niedbałości o siebie samego, pod względem już to ubioru, już to mieszkania i ekwipażu, słowem całego sposobu życia"98, było dobrym przykładem publicznego zaciekawienia tym, co dla Staszica było prywatne i intymne. Jego „niedbałość” pasowała do wizerunku filantropa, który w szczególny sposób podkreślał właśnie codzienną skromność. Ekscytacja osobowością czy dziwactwami była dość powszechnym trendem w wieku XIX, nie zawsze osobliwości w zachowaniu stanowiły jednak tak dobre uzupełnienie postaci, za którą publiczność miała Staszica. Objawów osobistej i „jednostronnej” relacji idola i fanów ${ }^{99}$ można się doszukiwać wśród apologetów i biografów filantropa (np. w bardziej przesyconych emocjami wypowiedziach Koźmiana) lub też niezwiązanych z nim osób, które poszukiwały inspiracji, samotnie odwiedzając jego grób.

Wskazywać można, tak jak robił to Skarbek, na charakterystyczną dla Staszica niechęć do bycia wyróżnianym czy też jego legendarną skromność, jako kontrastujące z popularnością widoczną na jego pogrzebie. Obydwie te cechy były jednak komplementarne wobec jego wizerunku filantropa-bohatera. Odmawiając więc sobie rozgłosu, Staszic znakomicie wkomponowywał się w swoją dobroczynną personę. Jednym z bardziej wyraźnych przykładów takich zachowań jest zapis testamentowy, w którym zastrzegał, że jego pochówek powinien być skromny, a przy jego trumnie „nie ma się palić więcej nad sześć świec” ${ }^{100}$. Instrukcja ta nie tylko nie została wypełniona, ale stała się wielokrotnie powtarzanym cytatem, który prasa wykorzystywała do uzasadnienia zasłużonej chwały dobroczyńcy ${ }^{101}$. Kontrast musiał być dostrzegany powszechnie, skoro w jednym ze swoich listów młody Fryderyk Chopin domyślał się, że jego korespondent, Jan Białobłocki, rezydujący w tym momencie w Biskupcu, słyszał o „suto-ubogim” pogrzebie Staszica ${ }^{102}$.

Poświadczeniem celebryckiego statusu Staszica jest też fakt, że zdawał on sobie sprawę z rozgłosu, jakim się cieszył, i w pewnym stopniu

${ }^{97}$ F. Skarbek, op. cit., s. 99-101.

98 Ibidem, s. 99.

99 Zob. C. Rojek, op. cit., s. 46-48.

100 S. Staszic, Autobiografia/Autobiography. Testament/Testament, red. J. Olejniczak, Piła 2005, s. 4.

101 „Kurier Warszawski” 1826, nr 33, s. 2; „Monitor Warszawski” 1826, 18, s. 1; „Gazeta Korrespondenta Warszawskiego y Zagranicznego” 1826, 15, s. 1-2.

102 Korespondencja Fryderyka Chopina, s. 154. 
kreował swój wizerunek. Wątek ten anegdotycznie podjęła Barbara Szacka w swojej klasycznej pracy z lat sześćdziesiątych ${ }^{103}$. To, że obraz Staszica był do pewnego stopnia autokreacją, można dostrzec, zwracając uwagę na momenty, w których nie potrafił on utrzymać się w narzuconej roli. Według raportu agenta policji, który śledził filantropa, miał on chadzać do teatru oraz „do miejsc, gdzie nie wypada bywać osobie duchownej" w komicznym przebraniu, zakładając płaszcz, perukę oraz fałszywe bokobrody, tak, aby uniknąć powiązania go z aktywnością najwyraźniej wizerunkowo niekorzystną. Fakt ten potwierdzają również inne źródła ${ }^{104}$.

Dziewiętnastowieczne ziemie polskie były też podatnym gruntem do rozwoju nowych form społecznego wyróżnienia. Przyczyniały się do tego wspomniane wcześniej procesy demokratyzacji i egalitaryzacji życia społecznego. Na ziemiach polskich czasów ponapoleońskich dostrzec można także wpływy „pierwszej rewolucji medialnej”, wskazywanej przez Liltiego. Choć nie w takiej skali jak na Zachodzie, od połowy XVIII w. w Rzeczypospolitej nastąpiła gwałtowna zmiana metod i technik drukarskich, skutkująca pojawieniem się środków przekazu takich jak dziennik, magazyn, pamflet, encyklopedia, książka specjalistyczna, ilustracje prasowe, muzyka drukowana oraz, oczywiście, powieść. W pierwszej połowie wieku XIX poligrafia zaczęła rozwijać się jeszcze bardziej dynamicznie ${ }^{105}$. Wzrost czytelnictwa, który można zaobserwować w tym okresie, przez niektórych wiązany jest z początkiem epoki mass mediów ${ }^{106}$. Polska scena literacka była również polem docenienia indywidualizmu i autentyczności, spełniając inny z warunków zaznaczonych przez Liltiego. Tendencje te pogłębiał zwrot romantyczny ${ }^{107}$. Z pewnością wskazać można skutki tych przemian: estetyzację oraz urynkowienie sfery publicznej, tzn. rosnące przywiązanie do wartości estetycznych i uzależnienie od fluktuacji rynkowych (np. rynku książki) dostrzegalne w sferze wymiany poglądów w społeczeństwie ${ }^{108}$.

Wyraźnym przykładem tego, jak sława Staszica różniła się od wcześniejszych form popularności, było funkcjonowanie jego wizerunku w prasie. Pamiętniki podkreślały, że w reakcji na jego śmierć „wszystkie

103 B. Szacka, op. cit., s. 219-221.

104 K.W. Wójcicki, Cmentarz Powązkowski pod Warszawa, t. 3, Warszawa 1858, s. 217.

105 T. Epsztein, M. Gawin, B. Dopart, Kominy, ludzie i obłoki. Modernizacja i kultura, Warszawa 2013, s. 246-249.

106 A. Briggs, P. Burke, Social History of the Media. From Gutenberg to Internet, Cambridge 2009, s. 105-117.

107 T. Epsztein, M. Gawin, B. Dopart, op. cit., s. 313-325.

108 G. Turner, Understanding Celebrity, London 2004, s. 134-140. 
nasze gazety zagrzmiały pochwałami i uwielbieniem"109 na skalę, której dotychczas nie spotykano. Od 21 stycznia do około 20 lutego temat zdominował media. „Kurier Warszawski” w 13 z 23 publikowanych w tym okresie numerów poczynił wzmiankę o Staszicu ${ }^{110}$. „Monitor Warszawski” poświęcił mu 6 not w 9 numerach publikowanych pomiędzy 21 stycznia a 9 lutego ${ }^{111}$, a "Gazeta Korrespondenta Warszawskiego y Zagranicznego" 7 z 12 wydanych w podobnym okresie (22 stycznia - 11 lutego) ${ }^{112}$. Tu również znaleźć można nawiązanie do badań nad celebrytami. Zjawisko charakteryzujące się przewagą jednego tematu w krótkim okresie czasu, ale $\mathrm{w}$ wielu różnych mediach określa się mianem flashpoint ${ }^{113}$. Dotychczas wskazywano na jego występowanie w początkach wieku XX. Fakt, że w ciągu kilku tygodni warszawska sfera publiczna przepełniła się przejawami entuzjazmu i poruszenia przekazywanymi przez liczne kanały komunikacyjne: publikacje prasowe, twórczość poetycką, wystąpienia publiczne czy pogłoski, stanowić może jednak jego wcześniejszy korzeń, ponownie łączący postać Staszica z przemianami w obrębie sławy.

Niektórzy badacze sławy uzależniają pojawienie się celebrytów od obecnej w społeczeństwie nadwyżki kapitału kulturowego, którą najłatwiej wyjaśnić jako potencjał do adaptacji lub wytworzenia nowych idei, wiedzy oraz umiejętności w obrębie społeczeństwa. Powstanie takiej nadwyżki wiąże się z dynamizacją stosunków społecznych i przekłada się na postęp cywilizacyjny oraz ekonomiczny (wzrost zamożności, rozwój przemysłowy, zwiększenie siły nabywczej) ${ }^{114}$. Innymi słowy, za polepszeniem się warunków materialnych idzie siła kulturotwórcza, która może przeistoczyć się w taki konstrukt jak „celebrytyzm”. Taką sytuację faktycznie obserwujemy w miastach polskich w pierwszej połowie wieku XIX, szczególnie w latach 1815-1830. Poczucie nagromadzenia kapitału było wyraźnie dostrzegalne w Warszawie, o której pisano we współczesnej prasie, że jej „ludność coraz bardziej wzrasta, gdy wznoszą się prawie codziennie gmachy, które jej dalszy postęp wróżą"115. O podobnym przekonaniu świadczy relacja Koźmiana, dla którego Warszawa „zaczęła być na nowo stolicą nauk i obyczajów polskich”, a jej mieszkańcy wkroczyli

109 T. Lipiński, op. cit., s. 17.

110 „Kurier Warszawski” 1826, nry 20, 22, 24-27, 29, 32, 33, 36, 37, 40 i 42.

111 „Monitor Warszawski” 1826, nry 10-13, 15, 18.

112 „Gazeta Korrespondenta Warszawskiego y Zagranicznego” 1826, nry 13-15, 18, 21, 23, 24.

${ }^{113}$ G. Turner, F. Bonner, P.D. Marshall, Fame Games. The Production of Celebrity in Australia, Cambridge 2000, s. 5-6; G. Turner, op. cit., s. 90-91.

114 C. Rojek, op. cit., s. 31-32; J. Gibbons, Art and Advertising, New York 2005, s. 152-154.

115 „Kurier Warszawski” 1821, 1, s. 2. 
w „byt materjalny najszczęśliwszy, mnóstwo pieniędzy”, co objawiało się „przez zabawy, uczty, wesołość” i „wszelki pozór szczęścia”"116. Cofając się do teorii Eisenstadta, można więc powiedzieć, że w rzeczywistości polskiej potrzeba nowych wzorców związanych z tożsamością zbiorową skorelowała się w czasie ze sprzyjającymi warunkami do wzrostu sławy żyjących postaci. W tym upatrywać należy odpowiedzi na pytanie, dlaczego to żyjąca, a nie historyczna postać stała się poszukiwanym wzorem osobowym.

\section{Wnioski}

Powyższe kontekstualizacje pozwalają wyjaśnić kilka tajemnic związanych z popularnością Staszica. Jego pogrzeb odbył się w okresie przemian tożsamości zbiorowej Polaków. Przedefiniowano takie pojęcia jak patriotyzm, obywatelstwo, prawo stanowe i przywództwo. Był to też czas docenienia indywidualizmu i autentyczności. Jeszcze niedawno wokół najbardziej kultowej postaci epoki, Napoleona, narosło grono bohaterów, ale ich sprawa upadła. Społeczeństwo Królestwa Kongresowego potrzebowało nowych wzorców, żeby lepiej oddać swój nowy kształt. Prasa, coraz bardziej przypominająca literaturę, jeśli chodzi o szczegółowość przedstawiania detali dotyczących życia celebrytów, których śledziła, skłaniała się do dostrzeżenia w takim herosie również człowieka. Staszic okazał się osobą, która łączyła te cechy - był gorliwym patriotą, ale również ofiarą złośliwych plotek i własnych drobnych frustracji, co czyniło go autentycznym w oczach publiczności. Jednocześnie jako znany filantrop i humanitarysta stanowił on najsilniejsze polskie odniesienie do nowego zestawu wartości, które przyjmował cały modernizujący się świat. Społeczna reakcja na jego śmierć powinna być rozumiana właśnie w tym kontekście - jako kierowana chęcią uczczenia nowego rodzaju bohatera narodowego, filantropa i celebryty.

Pogrzeb Staszica był jednym z najwcześniejszych przypadków korelacji charytatywnych idei oraz mechanizmów sławy w polskiej historii. W tekście wspomniano o jego odpowiednikach w krajach zachodnich. Jako że instytucjonalizacja funkcji społecznej filantropa przypada dopiero na drugą połowę XIX w., przypuszczać można, że wyżej wspomniane wydarzenia były pierwszymi, podczas których określono wzorzec filantropijny w przestrzeni publicznej (w przeciwieństwie do elitarnych pism,

${ }^{116}$ K. Koźmian, Pamiętniki, s. 247-8. Zob. J. Czubaty, Księstwo Warszawskie (1807-1815), Warszawa 2011, s. 283-318. 
np. filozoficznych). Dalsze badania przyczynić się mogą do określenia początków tego, kim dziś jest dla nas filantrop, choć trzeba zaznaczyć, że od początku wplątany był w relację ze sławą i opinią publiczną.

Warto dodać jeszcze jedno. W trakcie docierania do źródeł sławy Staszica skorzystano z założenia o historycznym korzeniu zjawiska celebrytyzmu, w najnowszej literaturze datowanym na wiek XVIII. Przyjęcie tej perspektywy nie tylko wzbogaciło, ale uściśliło opis charakteru popularności opisywanej postaci. Pozwoliło też wyjaśnić rolę mediów i środowisk opiniotwórczych w procesie atrybucji wyjątkowego statusu Staszicowi. Skłania to do zastanowienia, na ile ustalenia celebrity studies mogą być cennym wkładem w badanie genezy sławy innych popularnych postaci i służyć może za nieśmiały przykład pożytku płynącego z badań nad sławą na gruncie historycznym. Mimo rosnącego zainteresowania tematem, celebrity wciąż czeka na swojego historyka.

\section{Streszczenie}

Zaskakująca popularność Stanisława Staszica (1755-1826) najpełniej wyraziła się w jego pogrzebie, który zgromadził tysiące mieszkańców stolicy i wzbudził „szał uniesienia" uczuć patriotycznych. Zarówno stopień jego uwielbienia, jak i odrzucenie wszelkich kontrowersji związanych ze zmarłym mocno zdumiały mu współczesnych. Prasa i pamiętniki potwierdzają niezwykłe wrażenie, jakie pogrzeb wywarł na Polakach.

Autor wylicza uproszczone interpretacje tego zjawiska i udowadnia ich bezzasadność. Zaznacza również trendy, w które wpisywał się entuzjazm uczestników pogrzebu, dostrzegając, że nie w pełni wyjaśniają one zagadnienie. Część wątpliwości wyjaśnić można docenieniem roli filantropa, jaką przypisywano Staszicowi w końcowym etapie jego życia. Część artykułu poświęcona jest opisowi ewolucji tego wizerunku, od pochwały założyciela Towarzystwa Hrubieszowskiego na publicznym posiedzeniu Towarzystwa Przyjaciół Nauk w 1824 r., do powstania listopadowego. Szczególną uwagę zwrócono na różne media, które pomagały rozpowszechnić filantropijny obraz Staszica.

Przedmiotem opisu są również zjawiska społeczne, które autor uważa za kluczowe dla stworzenia sytuacji historycznej umożliwiającej przypisanie Staszicowi roli filantropa. Nowy model filantropii przenosił skojarzenie z dobroczynnością z wartości religijnych na obywatelskie i humanitarne. Proces przemiany tożsamości zbiorowej porozbiorowego społeczeństwa polskiego tworzył potrzebę znalezienia nowego rodzaju wzorców osobowych. W końcu, transformacje zjawiska sławy związane z postępem ekonomicznym $i$ technologicznym ukierunkować miały tę potrzebę na żyjące niedawno postacie, z którymi można było jednocześnie się identyfikować i je podziwiać. 


\section{The Immortal and the Philanthropic. Historical Research into the Origins and Nature of Stanisław Staszic's Fame}

The puzzling popularity of Stanisław Staszic (1755-1826) expressed itself most fully during his funeral which was attended by thousands of people and incited "a fury" of patriotic feelings. His contemporaries were amazed both at the depth of admiration for him, and rejection of all controversies in relation to his person. The press and memoirs confirm the unusual impression Staszic's funeral made on Polish people.

The author lists all the simplified interpretations present in the literature so far and argues for their insufficiency. Other solutions he mentions cover the explanation of the phenomenon only partially. As the author suggests, some unclarities could be explained by the philanthropic image ascribed to Staszic at the end of his life. One part of the present study describes the evolution of his image, from praise of the founder of the Hrubieszów Agricultural Society at the public session of the Society of Friends of Learning in 1824 to the November Uprising. Special attention was paid to various media that facilitated the spread of Staszic's image as philanthropist.

The author also presents the trends he considers fundamental to the creation of such a specific historical situation that made it possible for Staszic to be enthusiastically recognized. A new model of philanthropy shifted the notion of charity from religious values to civic and humanitarian values. A process of changes in the collective individuality of the post-partition Polish society created the need for a new type of role model. Finally, the transformations of the phenomenon of fame brought about by the economic and technological progress would direct this need to recently deceased people, who could be admired and put forward as an example.

Translated by Grażyna Waluga

\section{Bibliografia}

Aleksandrowska Elżbieta, Staszic Stanisław (1755-1826), w: Bibliografia Literatury Polskiej „Nowy Korbut”, t. 6: Oświecenie - hasła osobowe P-Ż, addenda A-O, oprac. Elżbieta Aleksandrowska z zespołem, red. tomu do r. 1958 Tadeusz Mikulski, PIW, Warszawa 1970, s. 219-235.

Andrew Donna, Philanthropy and Police. London Charity in the Eighteenth Century, Princeton University Press, Princeton 2014.

Bennett James, Historicising Celebrity Studies, „Celebrity Studies” 1, 2010, 3, s. 358-359. Biskupski Mieczysław B.B., Independence Day. Myth, Symbol and the Creation of Modern Poland, Oxford University Press, Oxford 2012.

Bratkowski Stanisław, Pieśni narodowe i sielanki, w Drukarni i nakł. J. Wróblewskiego, Warszawa 1827.

Briggs Asa, Burke Peter, Social History of the Media. From Gutenberg to Internet, Polity, Cambridge 2009. 
Burszta Wojciech J., Nowak Joanna, Wawruch Krzysztof, Od narodu szlacheckiego do państwa narodowego, w: Polska refleksja nad narodem. Wybór tekstów, red. iidem, Wydawnictwo Poznańskie, Poznań 2002, s. 9-14.

Cervantes Gabriel, Porter Dahlia, Extreme Empiricism. John Howard, Poetry, and the Thermometrics of Reform, „The Eighteenth Century” 57, 2016, 1, s. 95-119.

Cieszkowski Stanisław, Stanisław Staszic. filantrop, mąż stanu i uczony, ur. 1755 zm. 1826. zarys biograficzny w setna rocznice zgonu, Bibljoteka Domu Polskiego, Warszawa 1925.

Czubaty Jarosław, Księstwo Warszawskie (1807-1815), Wydawnictwo UW, Warszawa 2011.

Czubaty Jarosław, Zasada „dwóch sumieñ”. Normy postępowania i granice kompromisu politycznego Polaków w sytuacjach wyboru (1795-1815), Neriton, Warszawa 2005.

Devereaux Simon, Recasting the Theatre of Execution. The Abolition of the Tyburn Ritual, „Past \& Present” 202, 2009, 1, s. 127-174.

Dziennik posiedzeń Izby Poselskiey w czasie seymu Królestwa Polskiego w roku 1820 odbytego, wyd. Księży Pijarów, Warszawa [1820].

Eisenstadt Shmuel, Programy kulturowe, budowanie tożsamości zbiorowych i nieustająca rekonstrukcja pierwotności, w: idem, Utopia i nowoczesność. Porównawcza analiza cywilizacji, Oficyna Naukowa, Warszawa 2009.

Encyklopedia teatru polskiego, oprac. Bożena Frankowska, PWN, Warszawa 2003.

Epsztein Tadeusz, Gawin Magdalena, Dopart Bogusław, Kominy, ludzie i obłoki. Modernizacja i kultura, DiG, Warszawa 2013 (Historie Polski w XIX wieku, t. 1).

Gaszyński Konstanty, Wiersz na zgon Stanisława Staszica, Warszawa 1826.

Gąsiorowski Franciszek, Wiersz na zgon Stanisława Staszica, Warszawa 1826.

Geremek Bronisław, Litość i szubienica. Dzieje nędzy i miłosierdzia, Czytelnik, Warszawa 1989.

Gibbons Joan, Art and Advertising, I.B. Tauris, New York 2005.

Goldszmit Jakub, Dobroczyńca, jakich mało. Ksiadz Stanisław Staszic jako filantrop i mąż stanu. Szkic biograficzny, Skład Główny u Jana Poznańskiego, Warszawa 1882.

Gołata Krzysztof, Transformacja gospodarcza - nowe pojęcie przedsiębiorcy, „Zeszyty Naukowe Wyższej Szkoły Bankowej w Poznaniu" 24, 2009, s. 174-181.

Hahn Wiktor, Stanisław Staszic. Życie i dzieła (z portretem Staszica), Druk. Państwowa, Lublin 1926.

Himmelfarb Gertrude, The Roads to Modernity. The British, French, and American Enlightenments, Knopf, New York 2008.

Jezierski Andrzej, Leszczyńska Cecylia, Historia gospodarcza Polski, Key Text, Warszawa 1997.

Kaliński Janusz, Historia gospodarcza XIX i XX w., PWE, Warszawa 2004.

Kępski Czesław, Idea miłosierdzia a dobroczynność $i$ opieka, Wydawnictwo UMCS, Lublin 2002.

Kizwalter Tomasz, Historia powszechna. Wiek XIX, Trio, Warszawa 2007.

Korespondencja Fryderyka Chopina, t. 1: 1816-1831, oprac. Zofia Helman, Zbigniew Skowron, Hanna Wróblewska-Straus, Wydawnictwa UW, Warszawa 2009.

Kowalczykowa Alina, Piłsudski i tradycja, Verba, Chotomów 1991.

Kowalewski Zdzisław, Społeczeństwo obywatelskie $w$ doświadczeniu historycznym, Pax, Warszawa 1991. 
Koźmian Kajetan, Pamiętniki obejmujące wspomnienia od roku 1780 do roku 1815, t. 2, Jan Konstanty Żupański, Poznań 1858.

Koźmian Kajetan, Ziemiaństwo polskie. Poema w cztérech pieśniach, wyd. Edwarda Raczyńskiego, u Z. Schlettera, Wrocław 1839.

Kraushar Aleksander, Towarzystwo Królewskie Przyjaciół Nauk, 1800-1832. Monografia historyczna osnuta na źródłach archiwalnych, ks. 3: Czasy Królestwa Kongresowego. Czterolecie przedostatnie, 1824-1828, G. Gebethner i Spółka, Kraków 1905.

Kraushar Aleksander, Towarzystwo Warszawskie Przyjaciót Nauk 1800-1832. Monografia historyczna osnuta na źródłach archiwalnych, ks. 4: Czasy polistopadowe. Epilog. 1831-1836, G. Gebethner i Spółka, Kraków-Warszawa 1906.

Krysiak Franciszek S., Staszic jako polityk, uczony i filantrop, „Tygodnik Przemysłowy” 4, 1888, 2, s. 12-24.

Lach-Szyrma Krystyn, Anglia i Szkocja. Przypomnienia z podróży roku 1820-1824 odbytej, wyd. Paweł Hertz, PIW, Warszawa 1981.

Laske Jan, Z problematyki legendy napoleońskiej, w: Młoda Polska. Legendy i światopoglądy, red. Tadeusz Bujnicki, Jerzy Illg, Uniwersytet Śląski, Katowice 1983.

Lelewel Joachim, Polska odradzająca się, czyli dzieje polskie od roku 1795 potocznie opowiedziane, w drukarni P.-J. Vogleta, Bruksela 1836.

Leszczyński Jan Nepomucen, Elegija na zgon JW. Stanisława Staszica Ministra Stanu Prezesa Towarzystwa Przyjaciół Nauk, Warszawa 1826.

Leś Ewa, Zarys historii dobroczynności i filantropii w Polsce, Prószyński i S-ka, Warszawa 2001.

Lilti Antoine, Le monde des salons. Sociabilité et mondanité à Paris au XVIII siècle, Fayard, Paris 2005.

Lilti Antoine, The Invention of Celebrity. 1750-1850, Polity, Cambridge 2017 (wyd. oryg. Figures publiques. L'invention de la célébrité (1750-1850), Fayard, Paris 2014).

Lipiński Tymoteusz, Zapiski z lat 1825-1831, do dr. przygot. i przypisami objaśnił Kazimierz Bartoszewicz, nakł. K. Bartoszewicza, Kraków 1883.

Maksimowicz Krystyna, Poetycka legenda Tadeusza Kościuszki (lata 1792-1794), „Wiek Oświecenia” 11, 1995 (W dwusetną rocznicę Powstania Kościuszkowskiego), s. 65-81.

Maludzińska Monika, „Kraj jest nieszczéśliwy, że ma ludzi próżnujacych”. Walka z ubóstwem w Warszawie na tle sytuacji społeczno-gospodarczej Rzeczypospolitej w dyskursie publicystycznym drugiej połowy XVIII wieku, Neriton, Warszawa 2015.

Markiewicz Henryk, Pozytywizm, IBL PAN, Warszawa 1999.

Marshall P. David, Celebrity and Public Persona, Oxford Bibliographies, www.oxfordbibliographies.com/view/document/obo-9780199756841/obo-97801997568410159.xml (dostęp 29 VI 2017).

Matlęgiewicz Tomasz, Program słowiański Staszica po postanowieniach kongresu wiedeńskiego, „Przegląd Nauk Historycznych” 10, 2011, 1, s. 187-204.

Mazur Elżbieta, Dobroczynność w Warszawie XIX wieku, IAiE PAN, Warszawa 1999.

McCully George, Philanthropy Reconsidered. Private Initiatives, Public Good, Quality of Life (A Catalogue for Philanthropy Publication), AuthorHouse, Bloomington 2008.

Moniz Amanda, From Empire to Humanity. American Revolution and the Origins of Humanitarianism, Oxford University Press, Oxford 2016. 
Morgan Rod, Divine Philanthropy. John Howard Reconsidered, „History” 62, 1977, 206, S. $388-410$.

Morgan Simon, Historicising Celebrity, „Celebrity Studies” 1, 2010, 3, s. 366-368.

Niemcewicz Julian Ursyn, 0 więzieniach publicznych czyli domach pokuty rzecz krótka, N. Glücksberg, Warszawa 1818.

Nowak Andrzej, Polski patriotyzm wieku niewoli: trzy formuły?, w: Patriotyzm Polaków. Studia z historii idei, red. Jacek Kloczkowski, Ośrodek Myśli Politycznej, Wyższa Szkoła Europejska im. ks. J. Tischnera, Kraków 2006, s. 73-94.

Nowak Joanna, Duchowe piętno społeczeństw. Złożoność i przeobrażenia polskiej refleksji nad narodem $w$ XIX wieku, Slawistyczny Ośrodek Wydawniczy, Warszawa 2008.

Nowak Joanna, Naród i narodowość w polskiej myśli romantycznej, w: Naród-Tożsamość-Kultura. Między koniecznościa a wyborem, red. Wojciech J. Burszta, Krzysztof Jaskułowski, Joanna Nowak, Slawistyczny Ośrodek Wydawniczy, Instytut Slawistyki PAN, Warszawa 2005, s. 201-212.

O rok ów... Epoka napoleońska w polskiej historiografii, literaturze, sztuce i tradycji, red. Marian M. Drozdrowski, Hanna Szwankowska, Typografika, Warszawa 2003.

Olejniczak Józef, Staszicowskie wzorce w społeczeństwie polskim w XIX i XX wieku. Zarys problematyki, „Rozprawy z Dziejów Oświaty” 45, 2006, s. 23-33.

Ossowska Maria, Ethos rycerski i jego odmiany, PWN, Warszawa 2000.

Ossowska Maria, Moralność mieszczańska, Ossolineum, Wrocław 1985.

Paleczny Tadeusz, Socjologia tożsamości, Krakowskie Towarzystwo Edukacyjne - Oficyna Wydawnicza AFM, Kraków 2008 (Rejony Humanistyki 1).

Piosnki wieśniacze znad Niemna i Dźwiny, niektóre przysłowia i idiotyzmy, w mowie Sławiano-Krewickiej, s postrzeżeniami nad nią uczynionemi, [Jan Czeczot], drukiem Józefa Zawadzkiego, Wilno 1846.

Piotrowska-Marchewa Monika, Nędzarze i filantropi. Problem ubóstwa w polskiej opinii publicznej w latach 1815-1863, Adam Marszałek, Torun 2004.

Pochodaj Andrzej, Śmierć „polskiego Bayarda” - z legendy księcia Józefa Poniatowskiego, „Dzieła i Interpretacje” 4, 1996, s. 192-217.

Podgórska-Klawe Zofia, Od hospicjum do wspótczesnego szpitala. Rozwój problematyki szpitalnej w Polsce do końca XIX wieku, Ossolineum, Wrocław 1981.

Rojek Chris, Celebrity, Routledge, London-New York 2004.

Skarbek Fryderyk, Pamiętniki, Jan Konstanty Żupański, Poznań 1878.

Skarbek Fryderyk, Szweykowski Wojciech, Grzymała Wojciech, Zbiór mów na obchodzie pogrzebowym x. Stanisława Staszica, ministra stanu, dyrektora jeneralnego przemysłu i kunsztów, prezesa Towarzystwa Królewskiego Warszawskiego Przyjaciół Nauk, kawalera Orderu Orła Białego i S. Stanisława I kl. itd., Drukarnia X.X. Pijarów, Warszawa 1826.

Społeczeństwo obywatelskie i jego reprezentacja (1493-1993). Praca zbiorowa, red. Juliusz Bardach, Wydawnictwo Sejmowe, Warszawa 1995.

Stanisław Staszic 1755-1826. Księga zbiorowa, red. Zygmunt Kukulski, M. Arct i S-ka, Lublin 1926-1928.

Staszic (Stanislas), w: Biographie universelle ancienne et moderne: histoire par ordre alphabétique de la vie publique et privée de tous les hommes, red. Louis-Gabriel Michaud, t. 40, Paris 1843, wyd. 2, s. 173-174. 
Staszic Stanisław, Autobiografia/Autobiography. Testament/Testament, red. Józef Olejniczak, Muzeum Stanisława Staszica, Piła 2005.

Stępnik Andrzej, Mity w wiązaniu narracji historycznej, „Klio. Czasopismo poświęcone dziejom Polski i powszechnym" 34, 2015, 3, s. 6-18.

Szacka Barbara, Stanisław Staszic, PWN, Warszawa 1966.

Śreniowska Krystyna, Kościuszko bohater narodowy. Opinie wspótczesnych i potomnych. 1794-1946, PWN, Warszawa 1973.

Tomkowski Jan, Mój pozytywizm, IBL PAN, Warszawa 1993.

Treugutt Stefan, Napoleon Bonaparte jako bohater polskiego romantyzmu, „Teksty” 17, 1974, 5, s. 37-44.

Turkowski Tadeusz, o życiu i pracach Stanisława Staszica, dobroczyńcy narodu polskiego, Macierz Szkolna Ziem Wschodnich, Wilno 1926.

Turner Graeme, Bonner Frances, Marshall P. David, Fame Games. The Production of Celebrity in Australia, Cambridge University Press, Cambridge 2000.

Turner Graeme, Understanding Celebrity, Thousand Oaks: SAGE, London 2004.

Uwagi nad politycznym, naukowym i filantropijnym działaniem Stanisława Staszica, Jan Konstanty Żupański, Poznań 1873.

Wawrzyński Mirosław, Samopomoc i samoorganizacja Polaków od XIX do XXI wieku, Dom Wydawniczy „Duet”, Toruń 2007.

Wątroba Przemysław, Stanisława Staszica siedziby Towarzystwa Królewskiego Przyjaciót Nauk $w$ Warszawie. Rys historyczno-architektoniczny, „Wiek Oświecenia” 22, 2006 (Stanisław Staszic - myśliciel, pisarz, uczony), s. 117-143.

Wesołowski Adrian, „Celebrity studies” jako narzędzie dla historyka, „Historyka. Studia metodologiczne" 47, 2017, s. 325-332.

Widacka Hanna, Les adieux de Poniatowski czyli legenda księcia Józefa Poniatowskiego w grafice XIX wieku, „Kronika Zamkowa” 1995, 1, s. 98-114.

Wojda Aleksandra, Konstruktorzy pamięci. O etosie heroicznym w „Śpiewach historycznych" Juliana Ursyna Niemcewicza, w: Prace Herkulesa. Człowiek wobec wyzwań, prób i przeciwności, red. Maria Cieśla-Korytowska, Olga Płaszczewska, Wydawnictwo UJ, Kraków 2012, s. 127-148.

Wójcicki Kazimierz Władysław, Cmentarz Powązkowski pod Warszawą, t. 3, Warszawa 1858.

Zahorski Andrzej, Z dziejów legendy napoleońskiej w Polsce, PZWS, Warszawa 1971.

Biog ram: Adrian Wesołowski, doktorant na Wydziale Historycznym Uniwersytetu Warszawskiego oraz w Instytucie Antropologii Społecznej Maxa Plancka w Halle an der Saale; zainteresowania naukowe: lata 1750-1850, stosowanie metod nauk społecznych w badaniach historycznych, dzieje sławy, historia filantropii i dobroczynności; kontakt: wesolowskiad@gmail.com. 